\title{
Genomic insights into the fungal lignocellulolytic system of Myceliophthora thermophila
}

\author{
Anthi Karnaouri ${ }^{1,2+}$, Evangelos Topakas ${ }^{1+}$, lo Antonopoulou ${ }^{2}$ and Paul Christakopoulos ${ }^{2 *}$ \\ Biotechnology Laboratory, Department of Synthesis and Development of Industrial Processes, School of Chemical Engineering, National Technical University of \\ Athens, Athens, Greece \\ ${ }^{2}$ Biochemical Process Engineering, Chemical Engineering, Department of Civil, Environmental and Natural Resources Engineering, Luleå University of Technology, \\ Luleå, Sweden
}

\section{Edited by:}

Katherine M. Pappas, University of

Athens, Greece

Reviewed by:

Gianni Panagiotou, The University of

Hong Kong, Hong Kong

Ulrika Rova, Luleå University of

Technology, Sweden

*Correspondence:

Paul Christakopoulos, Biochemical Process Engineering, Chemical

Engineering, Department of Civil,

Environmental and Natural

Resources Engineering, Luleå

University of Technology, C-Building,

Universitetsområdet, Porsön,

SE-97187 Luleå, Sweden

e-mail:paul.christakopoulos@ltu.se

${ }^{\dagger}$ These authors have contributed

equally to this work.
The microbial conversion of solid cellulosic biomass to liquid biofuels may provide a renewable energy source for transportation fuels. Cellulolytic fungi represent a promising group of organisms, as they have evolved complex systems for adaptation to their natural habitat. The filamentous fungus Myceliophthora thermophila constitutes an exceptionally powerful cellulolytic microorganism that synthesizes a complete set of enzymes necessary for the breakdown of plant cell wall. The genome of this fungus has been recently sequenced and annotated, allowing systematic examination and identification of enzymes required for the degradation of lignocellulosic biomass. The genomic analysis revealed the existence of an expanded enzymatic repertoire including numerous cellulases, hemicellulases, and enzymes with auxiliary activities, covering the most of the recognized CAZy families. Most of them were predicted to possess a secretion signal and undergo through post-translational glycosylation modifications. These data offer a better understanding of activities embedded in fungal lignocellulose decomposition mechanisms and suggest that $M$. thermophila could be made usable as an industrial production host for cellulolytic and hemicellulolytic enzymes.

Keywords: Myceliophthora thermophila, plant biomass, lignocellulolytic enzymes, CAZy, biofuels

\section{INTRODUCTION}

Ethanol production from lignocellulosic biomass, comprised primarily of cellulose and hemicellulose, appears to evolve as one of the most important technologies for sustainable development. Given its renewable nature, biomass is a potential raw material not only for the production of biofuels, but also chemicals, energy and other materials of main industrial interest (Zhang et al., 2006). The monosaccharides contained in the cellulosic (glucose) and hemicellulosic fractions (xylose, arabinose, mannose, and galactose) represent substrates that can be used for ethanol production via fermentation. To initiate the degradation of these fractions, it is necessary to overcome the physical and chemical barriers presented by the cohesive combination of the main biomass components, which hinders the hydrolysis of cellulose and hemicellulose into fermentable sugars. The above include high substrate viscosity, poor mass transfer conditions and long reaction times, during which hydrolysis reactors are susceptible to contamination. Fungi are the main decomposers of lignocellulosic biomass in terrestrial ecosystems and the enzymes they secrete to break down lignocellulose may be useful in industrial processes. Thermophilic fungi provide a potential source of plant cell wall degrading enzymes with higher levels of specific activity and better stability at higher temperatures, thus making it feasible to minimize the hydrolysis time, reduce substrate viscosity and contamination levels (Margaritis and Merchant, 1986).

Myceliophthora thermophila (synonym Sporotrichum thermophile) is a thermophilic filamentous fungus, classified as an ascomycete, which was isolated from soil in eastern Russia and constitutes an exceptionally powerful cellulolytic organism, which synthesizes a complete set of enzymes necessary for the breakdown of cellulose. The growth rate and cell density of this microorganism appear to be similar in media containing cellulose or glucose (Bhat and Maheshwari, 1987). The 38.7 Mbp genome of $M$. thermophila, comprising about 9500 genes, organized in 7 chromosomes, has been sequenced and annotated (Joint Genome Institute, University of California, http:// genome.jgi-psf.org; Berka et al., 2011). It revealed a large number of genes putatively encoding industrially important enzymes, such as carbohydrate-active enzymes (CAZy), proteases, oxidoreductases, and lipases, while more than 200 sequences have been identified exclusively for plant cell-wall-degrading enzymes. These sequences encode a large number of glycoside hydrolases (GH) and polysaccharide lyases, covering the most of the recognized families (Table 1). In addition, M. thermophila was developed into a proprietary mature enzyme production system with easy scaling (C1 strain; Visser et al., 2011). The main features of $\mathrm{C} 1$ are the high production levels (up to $100 \mathrm{~g} / \mathrm{L}$ protein), as well as the maintenance of low viscosity levels of the culture medium, thus enabling fermentation process to reach very high densities.

$M$. thermophila exhibits an impressing number of accessory enzymes belonging to AA9 (previously described as GH61) and family 1 carbohydrate binding modules (CBM), which are the highest found in fungi (Berka et al., 2011). Family 1 CBM presents a cellulose-binding function and is almost exclusively found in 
Table 1 | Number of predicted CAZymes encoded in the genome of M. thermophila.

\begin{tabular}{|c|c|c|c|}
\hline \multicolumn{2}{|c|}{ Specific activity } & \multirow{2}{*}{$\begin{array}{c}\text { CAZy module(s) } \\
\text { GH 5, 7, 12, } 45\end{array}$} & \multirow{2}{*}{$\begin{array}{c}\text { No. id. seq } \\
8\end{array}$} \\
\hline Cellulases & Endoglucanases & & \\
\hline & Cellobiohydrolases & $\mathrm{GH} 6,7$ & 7 \\
\hline & $\beta$-glucosidases & $\mathrm{GH} 1,3$ & 8 \\
\hline & LPMOs & AA9 & 25 \\
\hline \multirow[t]{2}{*}{ Xylanases } & Xylanases & $\mathrm{GH} 10,11$ & 12 \\
\hline & Xylosidases & $\mathrm{GH} 3,43$ & 4 \\
\hline \multirow[t]{2}{*}{ Arabinases } & Endoarabinases & $\mathrm{GH} 43$ & 3 \\
\hline & $\begin{array}{l}\text { Exo-arabinases/ } \\
\text { arabinofuranosidases }\end{array}$ & $\mathrm{GH} 43,51,62$ & 11 \\
\hline \multirow[t]{2}{*}{ Mannanases } & Endomannanases & $\mathrm{GH} 5,26$ & 3 \\
\hline & Mannosidases & $\mathrm{GH} 2$ & 2 \\
\hline \multirow[t]{4}{*}{ Pectinases } & Polygalacturonases & $\mathrm{GH} 28$ & 2 \\
\hline & Rhamnosidases & GH78 & 1 \\
\hline & Pectin lyases & PL 1, 3, 4, 20 & 8 \\
\hline & Pectin esterases & CE 8, 12 & 4 \\
\hline \multirow[t]{5}{*}{ Esterases } & Feruloyl esterases & CE 1 & 4 \\
\hline & Acetyl esterases & CE $3,5,16$ & 8 \\
\hline & $\begin{array}{l}\text { Acetylmannan } \\
\text { esterases }\end{array}$ & CE 12 & 2 \\
\hline & Glycuronoyl & CE 15 & 2 \\
\hline & esterases & & \\
\hline
\end{tabular}

GHs, Glycoside hydrolases; CEs, carbohydrate esterases; and PLs, polysaccharide lyases are included, covering the most of the recognized families.

enzymes of fungal origin (http://www.cazy.org; Guillén et al., 2009). In addition, $M$. thermophila distinguishes itself from other cellulolytic fungi, such as Aspergillus niger and Trichoderma reesei by the presence of a relatively high number of (glucurono) arabinoxylan degrading enzymes (Hinz et al., 2009). Eleven putative xylanases were found that belong into GH 10 and 11 families compared to five in both A. niger (Broad Institute of Harvard and MIT, http://www.broadinstitute.org) and T. reesei (Joint Genome Institute, University of California, http://genome. jgi-psf.org), while 14 arabinofuranosidases belonging to $\mathrm{GH} 43$, 51, and 62 families were found compared to 13 in A. niger and three in $T$. reesei, rendering $M$. thermophila a promising source of hemicellulolytic enzymes. Studying the secretome of $M$. thermophila after $30 \mathrm{~h}$ of growth in barley and alfalfa straws, it was found to comprise of 683 predicted proteins, 230 of which are proteins with unknown function (Berka et al., 2011). Based on transcriptome analysis, many secreted enzymes including accessory enzymes, hypothetical proteins and proteins with unknown function were upregulated, when the fungus is grown in more complex substrates, such as agricultural straws, compared to glucose, indicating their crucial role in lignocellulose degradation (Berka et al., 2011).

M. thermophila grows in temperatures between 25 and $55^{\circ} \mathrm{C}$, while a relative growth performance study on mycobroth agar plates indicated that the optimum condition is at $45^{\circ} \mathrm{C}$ (Morgenstern et al., 2012). The temperature optima for several enzymes with the same specific activity, characterized from M. thermophila, range from 50 to $70^{\circ} \mathrm{C}$. For example, StEG5 endoglucanase, expressed in A. niger, exhibits a $\mathrm{T}_{\mathrm{opt}}$ of $70^{\circ} \mathrm{C}$ (Tambor et al., 2012), while recombinant $M t E G 7$ expressed in Pichia pastoris exhibited an optimal temperature of $60^{\circ} \mathrm{C}$ (Karnaouri et al., 2014). The same characteristic is also observed for M. thermophila xylanases expressed in A. niger, showing optimal activity at temperatures between 50 and $70^{\circ} \mathrm{C}$ (Berka et al., 2011), underpinning the enzymatic potential that is not only diverse in catalytic activities, but also in properties increasing its efficiency in various temperatures.

Individual cellulolytic enzymes exhibit comparable activities on cellulose; however, synthetically composed multienzyme mixtures display a much higher performance than those from other lignocellulolytic thermostable fungi (Szijártó et al., 2011; Zhang et al., 2013). This can be attributed to synergistic mode of action between the enzymes. For example, synergism between GH 11 xylanase and type $\mathrm{C}$ feruloyl esterase has been proved (Moukouli et al., 2010), as well as between cellobiohydrolases acting on the reducing and the non-reducing end of cellulose molecules (Gusakov et al., 2007).

In this review, an overview will be given of the cellulolytic and hemicellulolytic potential of $M$. thermophila regarding the degradation of plant cell wall material. The genomic potential of this thermophilic fungus demonstrates a strong enzymatic toolbox including hydrolytic, oxidative and accessory activities that may enhance its ability to decompose plant biomass. Many of these enzymes have been isolated from culture supernatant or selectively overexpressed in M. thermophila (C1 strain) or in other heterologous hosts and have been characterized. All sequences used in this study were extracted from Genome Portal database (http://genome.jgi-psf.org) and the continually updated CAZy database (http://www.cazy.org/; Lombard et al., 2014). The conserved domains were found with Pfam/InterProscan (http:// pfam.sanger.ac.uk/; Punta et al., 2012), while the theoretical molecular mass and isoelectric point for each protein were calculated using the ProtParam tool of ExPASY (http://web.expasy. $\mathrm{org} /$ protparam/). Post-translational glycosylation sites were predicted with NetNGlyc 1.0 server (http://www.cbs.dtu.dk/services/ NetNGlyc/) and NetOGlyc 3.1 server (http://www.cbs.dtu.dk/ services/NetOGlyc/). Predicted secretome was extracted using SignalP v4.0 (http://www.cbs.dtu.dk/services/SignalP/).

\section{CELLULOLYTIC SYSTEM}

Cellulose is composed of $\beta$-D-anhydroglucopyranose units linked by $(1,4)$-glycosidic bonds. Polymorphism or allotropy refers to the existence of more than one crystalline forms differing in physical and chemical properties. Cellulose degradation is attributed to the synergistic action of three complementary enzyme activities: (1) endoglucanases (EGs, EC 3.2.1.4); (2) exoglucanases, including cellodextrinases (EC 3.2.1.74) and cellobiohydrolases (CBHs, EC 3.2.1.91 for the non-reducing end acting $\mathrm{CBHs}$ and EC 3.2.1.176 for the reducing end acting ones) and (3) $\beta$ glucosidases (BGs, EC 3.2.1.21) (Lynd et al., 2002). Amorphous regions of the polysaccharide chain are cleaved randomly by EGs, while $\mathrm{CBHs}$ remove processively cellooligosaccharides from chain ends. The latter are the most abundant enzymes in the secretome 
of cellulolytic fungi (Jun et al., 2011; Ribeiro et al., 2012). Their main representatives are $\mathrm{GH}$ family $7(\mathrm{CBH} \mathrm{I})$ that attack the reducing end of a cellulose chain and $\mathrm{GH}$ family 6 (CBH II) that are specific toward the non-reducing end of the chain. Until very recently, $\mathrm{CBH}$ s were considered as the main degraders of the crystalline part of cellulose (Sweeney and $\mathrm{Xu}, 2012$ ).

EGs are widespread among $\mathrm{GH}$ families, with examples described for families $5-9,12,44,45,48,51$, and 74 on the continually updated CAZy database (http://www.cazy.org/; Lombard et al., 2014). Most of them show optimal activity at neutral or acidic $\mathrm{pH}$ and at temperatures below $50^{\circ} \mathrm{C}$ (Maheshwari et al., 2000). Exo-glucanases (or CBHs) act in a processive manner (Davies and Henrissat, 1995) and are classified only to two families, as referred previously. One of the important features of all $\mathrm{CBH}$ s is that they can act on microcrystalline cellulose (Terri, 1997). BGs include enzymes of GH1 and GH3 families that hydrolyze cellobiose and short (soluble) cellooligosaccharides to glucose that could subsequently fermented to ethanol; e.g., the hydrolysis reaction is performed in the liquid phase, rather than on the surface of the insoluble cellulose particles, such as EGs and CBHs. The removal of cellobiose is an important step of the enzymatic hydrolysis process, as it assists in reduction of the inhibitory effect of cellobiose on EG and CBH. BG activity has often been found to be rate-limiting during enzymatic hydrolysis of cellulose (Duff and Murray, 1996; Tolan and Foody, 1999), and due to that the commercial cellulase enzyme preparations are often supplemented with BG activity.

Until recently, only hydrolytic enzymes were thought to play a role in the degradation of recalcitrant cellulose and hemicelluloses to fermentable sugars. Recent studies demonstrate that enzymes from the GH family 61 show lytic polysaccharide monooxygenase activity (LPMO) and have an enhancing cellulolytic effect when combined with common cellulases (Horn et al., 2012).
Together with cellobiose dehydrogenase (CDH; EC 1.1.99.18), an enzymatic system capable of oxidative cellulose cleavage is formed, which increases the efficiency of cellulases and boosts the enzymatic conversion of lignocellulose. It has long been thought that the proteins of GH family 61 are accessory proteins enhancing cellulose decomposition. They were thus frequently referred to as the "cellulose enhancing factors" (Harris et al., 2010) and previously thought to have no or only weak endoglucanase activity (Karlsson et al., 2001). Now, these enzymes are now reclassified to AA9 family of CAZy database and their mode of action provide a new dimension to the classical concept of cellulose degradation, as recently reviewed by Dimarogona et al. (2013). These copperdependent enzymes were shown to cleave cellulose by an oxidative mechanism provided that reduction equivalents from $\mathrm{CDH}$ or low molecular weight reducing agents (e.g., ascorbate) are available (Langston et al., 2011). In some genomes, AA9 genes even outnumber cellulose genes. It remains to be elucidated whether all of these encoded enzymes have PMO activity, but their large number emphasizes the importance of oxidative cellulose cleavage. M. thermophila's genome has 25 AA9 genes, encoding putative proteins acting as accessory LPMOs enzymes (Berka et al., 2011). This number is outstanding in comparison to common lignocellulolytic organisms, as $A$. niger (seven sequences) and $T$. reesei (nine sequences). This difference can explain the high efficiency of hydrolysis of Myceliopthora in nature substrates and reveals the crucial role of these enzymes in the whole procedure.

Throughout the genome of $M$. thermophila, there are eight sequences encoding EG activity, seven sequences of $\mathrm{CBH}$ activity and nine sequences of BG activity (Figure 1; Table 2). The theoretical average molecular weight of the translated proteins is calculated at $51.05 \pm 16.2 \mathrm{kDa}$ and the theoretical $\mathrm{pI}$ at $5.58 \pm 0.3$. EGs are distributed to families GH5, 7, 12, and 45, all predicted to possess a secretion signal and several $N$ - and $O$-glycosylation

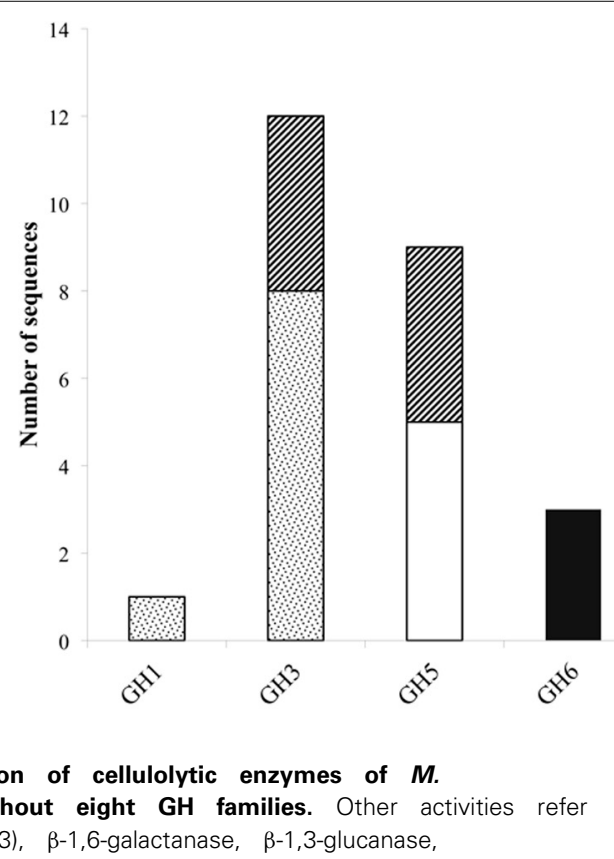

thermophila throughout eight GH families. Other activities refer to $\beta$-xylosidase (GH3), $\beta$-1,6-galactanase, $\beta$-1,3-glucanase,

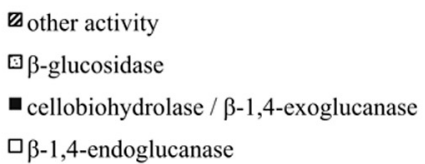

$\square \beta$-1,4-endoglucanase

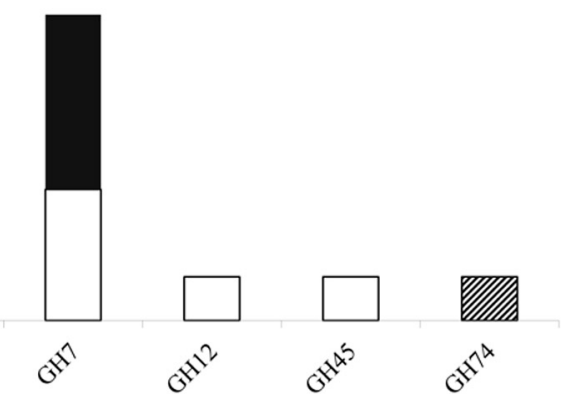

endo-1,4-beta-mannosidase or putative proteins with unknown function (GH5). GH74 represents xyloglucan specific 1,4-endoglucanase/xyloglucanase. 


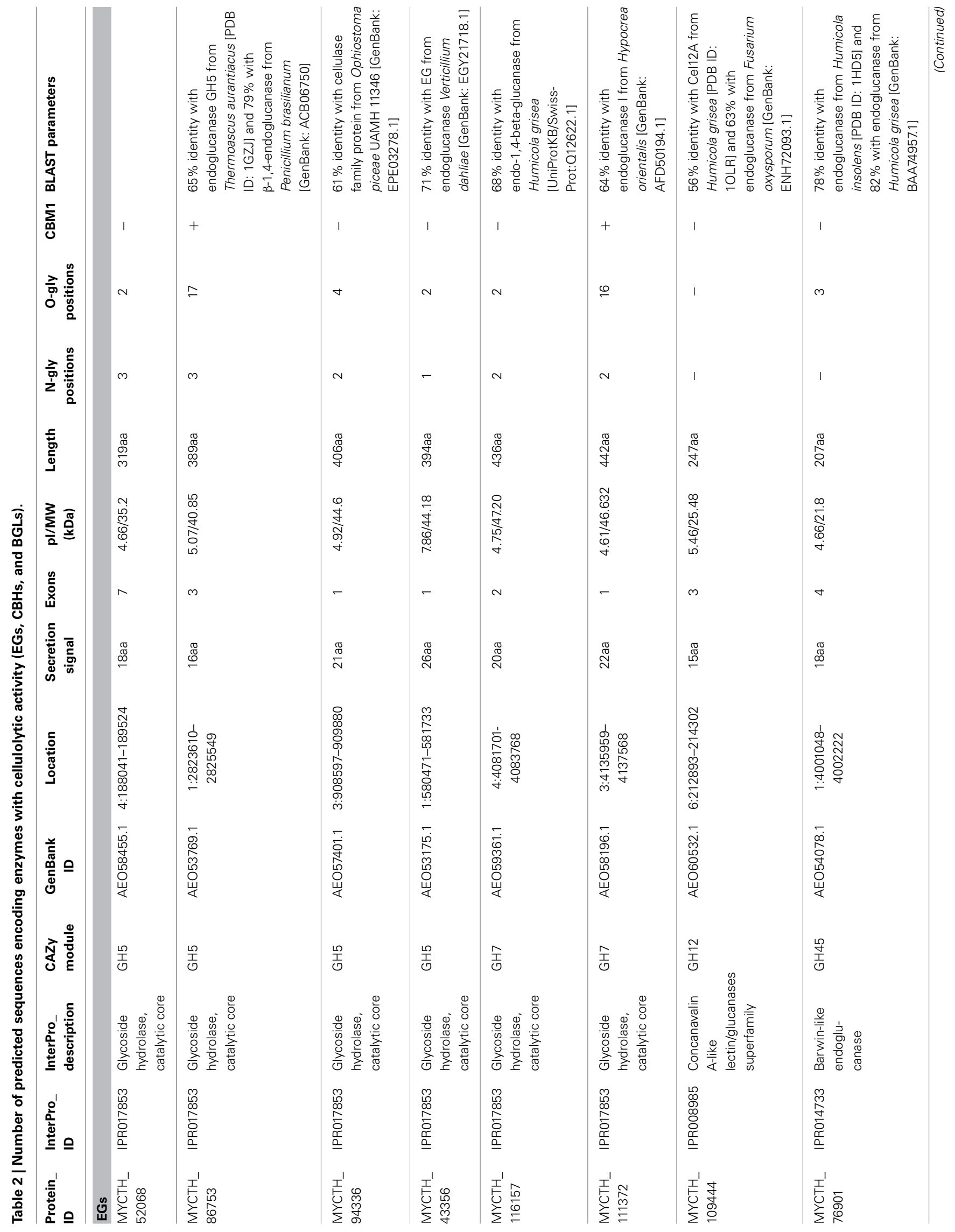




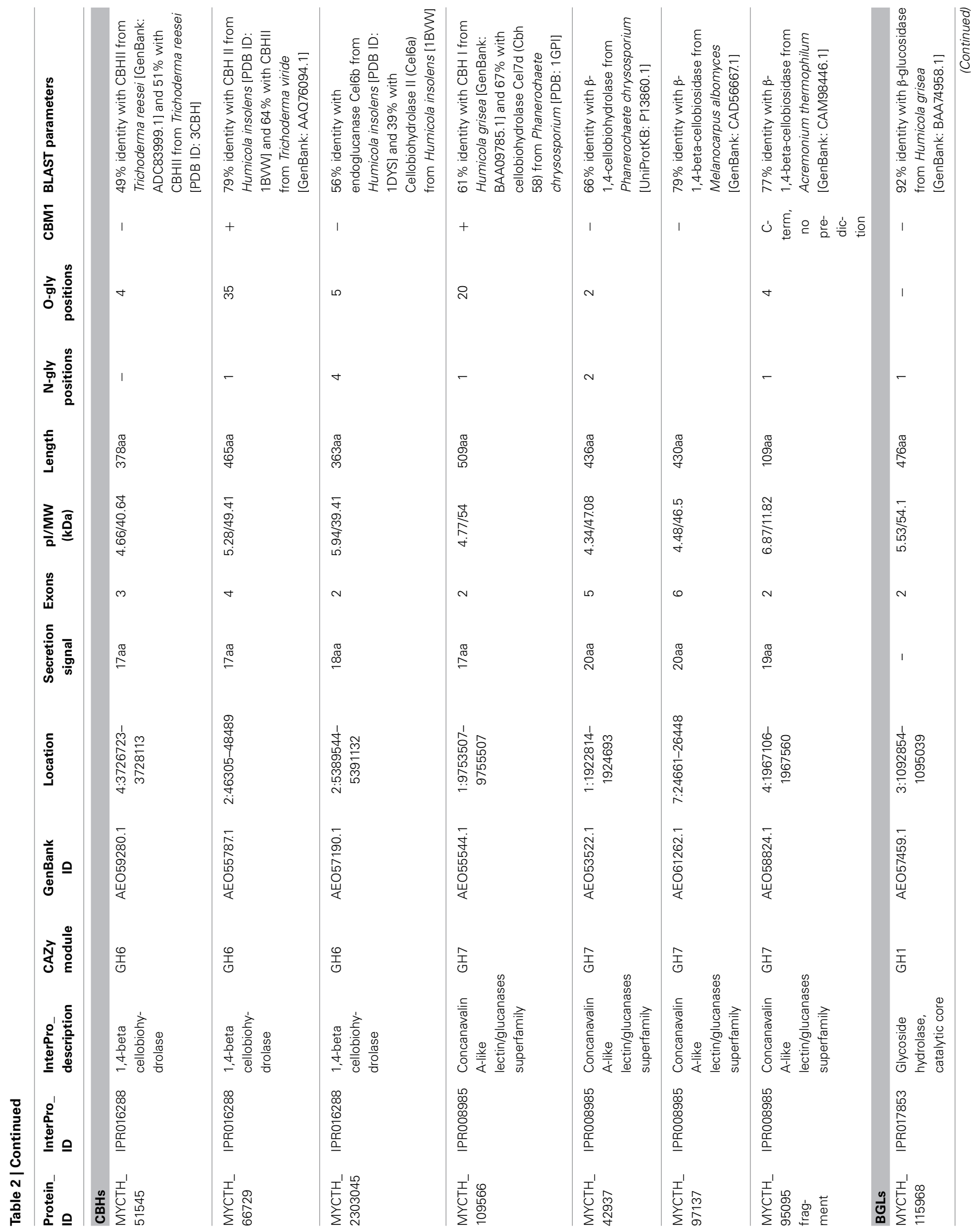




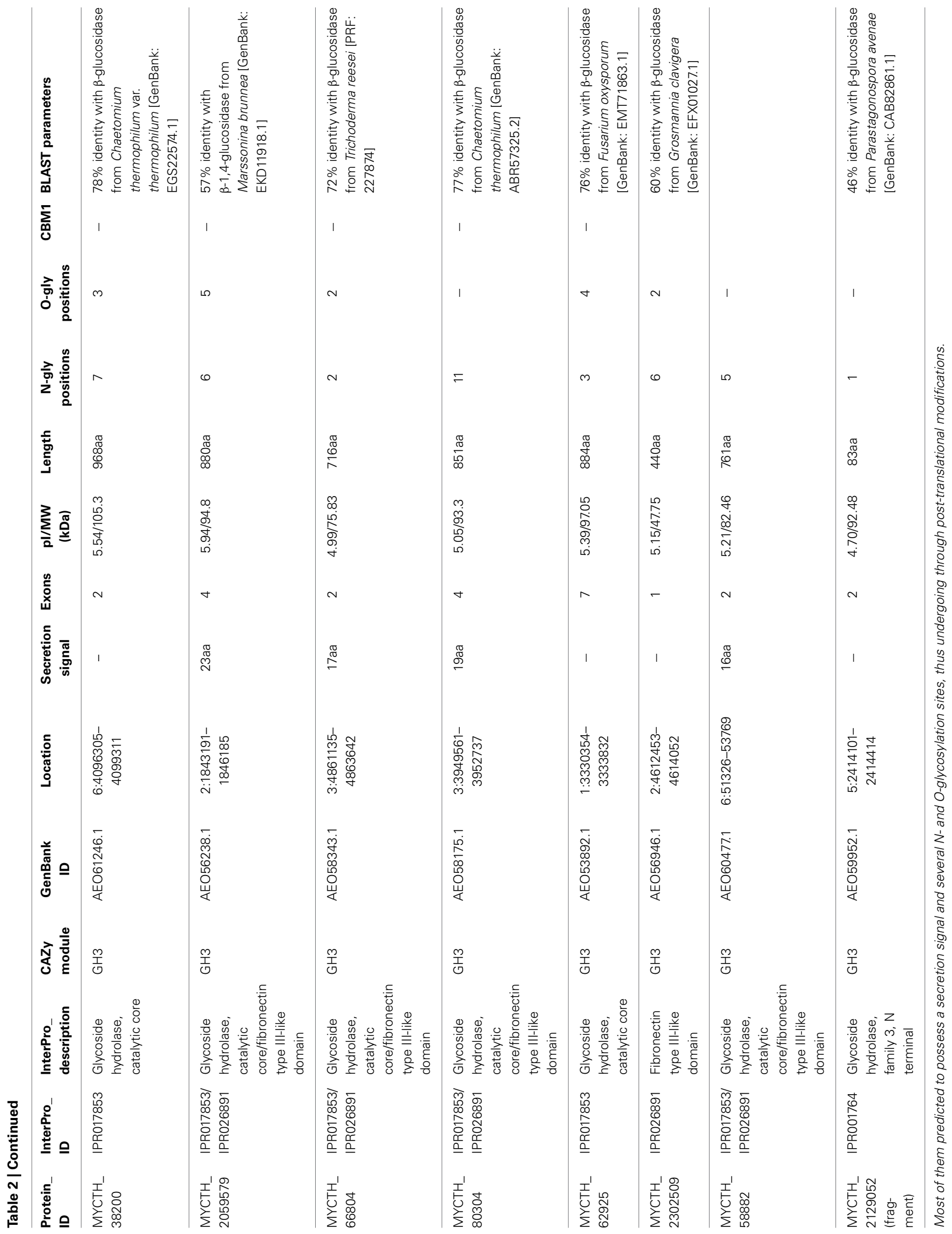


sites. Only two of them exhibit a CBM that belong in family 1 . $\mathrm{CBH}$ represent three non-reducing acting enzymes of GH6 family and four reducing-end acting enzymes of GH7 family. All of these enzymes seem to be targeted to secretion pathway and modified with glycans during post-translational modifications. BGs are classified to $\mathrm{GH} 3$ family, except one $\mathrm{GH} 1$ sequence, while none of them exhibit a CBM, as expected. Four are secreted and have potential $\mathrm{N}$ - and $\mathrm{O}$-glycosylation sites, showing the highest molecular weight compared to the other cellulases, with a theoretical average value of $85.18 \pm 3.2 \mathrm{kDa}$.

Totally, 12 cellulases have been isolated and characterized (Table 3). The group of Bukhtojarov et al. (2004) investigated the properties of individual cellulases from the multienzyme complex produced by a mutant strain of $M$. thermophila $\mathrm{C} 1$ (Visser et al., 2011). Among EGs, the highest saccharification activity was displayed by EG60 and EG51, representing enzymes of 60 and $51 \mathrm{kDa}$, respectively, which exhibited pI values of 3.6 and 5.0, respectively. It has been shown later that the EG51 and EG60 represent the GH5 and GH7 EGs from $M$. thermophila, respectively, (Gusakov et al., 2011). A different EG (StCel5A) displays a typical GH5 domain, exhibiting optimal activity at pH 6.0 and $70^{\circ} \mathrm{C}$ and retained greater than $50 \%$ of its activity following $2 \mathrm{~h}$ of incubation at $55^{\circ} \mathrm{C}$, diluted in $10 \mathrm{mM}$ citrate buffer $\mathrm{pH} 4.5$ (Tambor et al., 2012). A GH7 EG gene was functionally expressed in methylotrophic yeast $P$. pastoris and subsequently characterized (Karnaouri et al., 2014). Substrate specificity analysis revealed that the enzyme is one of the most thermostable fungal enzymes reported up to now and exhibits high activity on substrates containing $\beta$-1,4-glycosidic bonds as well as activity on xylancontaining substrates. Moreover, $M t$ EG7a was proved to liquefy rapidly and efficiently pretreated wheat straw, indicating EGs' key role to the initial step of hydrolysis of high-solids lignocellulose substrates (Karnaouri et al., 2014). This change in viscosity of these substrates is probably due to the gradual reduction of

Table 3 | Description of the characterized cellulolytic enzymes either isolated from the culture broth of a M. thermophila C1 mutant strain or expressed in a heterologous host.

\begin{tabular}{|c|c|c|c|c|c|c|c|c|c|}
\hline Enzyme & Type of action & GH & $\begin{array}{c}\text { MW-monomer } \\
\text { (kDa) }\end{array}$ & $\mathrm{pH}_{\mathrm{opt}}$ & $\mathrm{T}_{\text {opt }}\left({ }^{\circ} \mathrm{C}\right)$ & pl & Gene & Source & References \\
\hline StCel5A & Endoglucanase & 5 & 46 & 6 & 70 & ND & & $\begin{array}{l}\text { cDNA library-EST } \\
\text { analysis, expessed in } \\
\text { A. niger }\end{array}$ & $\begin{array}{l}\text { Tambor et al., } \\
2012\end{array}$ \\
\hline EG51 & Endoglucanase & 5 & 51 & 4.7 & 70 & 4.8 & & $\begin{array}{l}\text { Isolated from the } \\
\text { culture broth of a C1 } \\
\text { mutant strain }\end{array}$ & $\begin{array}{l}\text { Bukhtojarov et al., } \\
\text { 2004; Gusakov } \\
\text { et al., } 2005\end{array}$ \\
\hline MtEG7a & Endoglucanase & 7 & 65 & 5 & 60 & $\begin{array}{c}\text { Multiple bands } \\
\text { in 3.8-4.5 }\end{array}$ & eg7a & $\begin{array}{l}\text { Expressed in } P \text {. } \\
\text { pastoris }\end{array}$ & $\begin{array}{l}\text { Karnaouri et al., } \\
2014\end{array}$ \\
\hline EG60 & Endoglucanase & 7 & 60 & 4.7 & 60 & 3.7 & & $\begin{array}{l}\text { Isolated from the } \\
\text { culture broth of a } \mathrm{C} 1 \\
\text { mutant strain }\end{array}$ & $\begin{array}{l}\text { Bukhtojarov } \\
\text { et al., } 2004\end{array}$ \\
\hline EG28 & Endoglucanase & 12 & 28 & 5.35 & 60 & 5.7 & & $\begin{array}{l}\text { Isolated from the } \\
\text { culture broth of a C1 } \\
\text { mutant strain }\end{array}$ & $\begin{array}{l}\text { Bukhtojarov } \\
\text { et al., } 2004\end{array}$ \\
\hline EG25 & Endoglucanase & 45 & 25 & 5.5 & 65 & 4 & & $\begin{array}{l}\text { Isolated from the } \\
\text { culture broth of a C1 } \\
\text { mutant strain }\end{array}$ & $\begin{array}{l}\text { Bukhtojarov et al., } \\
\text { 2004; Gusakov } \\
\text { et al., } 2005\end{array}$ \\
\hline $\mathrm{CBH}$ la & $\begin{array}{l}\text { 1,4-beta } \\
\text { cellobiohydrolase }\end{array}$ & 7 & 65 & 5 & ND & 4.5 & & $\begin{array}{l}\text { Isolated from the } \\
\text { culture broth of a C1 } \\
\text { mutant strain }\end{array}$ & $\begin{array}{l}\text { Bukhtojarov et al., } \\
\text { 2004; Gusakov } \\
\text { et al., } 2005\end{array}$ \\
\hline $\mathrm{CBH} \| \mathrm{la}$ & $\begin{array}{l}\text { 1,4-beta } \\
\text { cellobiohydrolase }\end{array}$ & 6 & 43 & 5.4 & 65 & 4.2 & & $\begin{array}{l}\text { Isolated from the } \\
\text { culture broth of a C1 } \\
\text { mutant strain }\end{array}$ & $\begin{array}{l}\text { Bukhtojarov et al., } \\
\text { 2004; Gusakov } \\
\text { et al., } 2005\end{array}$ \\
\hline $\mathrm{CBH} \mathrm{lb}$ & $\begin{array}{l}\text { 1,4-beta } \\
\text { cellobiohydrolase }\end{array}$ & 7 & 60 & ND & ND & ND & & $\begin{array}{l}\text { Isolated from the } \\
\text { culture broth of a C1 } \\
\text { mutant strain }\end{array}$ & $\begin{array}{l}\text { Gusakov et al., } \\
2007\end{array}$ \\
\hline $\mathrm{CBH} I \mathrm{Ib}$ & $\begin{array}{l}\text { 1,4-beta } \\
\text { cellobiohydrolase }\end{array}$ & 6 & 70 & ND & ND & 5.6 & & $\begin{array}{l}\text { Isolated from the } \\
\text { culture broth of a C1 } \\
\text { mutant strain }\end{array}$ & $\begin{array}{l}\text { Gusakov et al., } \\
2007\end{array}$ \\
\hline MtBgl3a & beta-glucosidase & 3 & 90 & 5 & 70 & 4.0 & $b g / 3 a$ & $\begin{array}{l}\text { Expressed in } P \text {. } \\
\text { pastoris }\end{array}$ & $\begin{array}{l}\text { Karnaouri et al., } \\
2013\end{array}$ \\
\hline$B \times 15$ & beta-glucosidase & 3 & $120 \pm 5$ & 4.6 & 75 & 5.2 & $b \times 15$ & $\begin{array}{l}\text { Homologously } \\
\text { expressed in } \mathrm{C} 1\end{array}$ & $\begin{array}{l}\text { Dotsenko et al., } \\
2012\end{array}$ \\
\hline
\end{tabular}

Most of them exhibit optimum temperatures above $60^{\circ} \mathrm{C}$ and $\mathrm{pH}$ around 5.0 . 
the average chain length of cellulose polysaccharides by endoacting enzymes, such as endoglucanases. Totally, four CBHs and two BGs have been isolated from $M$. thermophila crude supernatant and studied. CBH IIb is the product of MYCTH_66729 gene that represents an enzyme of GH6 family, which is attached to polysaccharide substrate through a $\mathrm{CBM}$ and exhibits high levels of activity in comparison to other CBHs (Gusakov et al., 2007). In the same study, the isolation of $\mathrm{CBH}$ Ib, a GH7 family enzyme (MYCTH_2140736) is reported, which acts mainly against microcrystalline cellulose and CMC. Bukhtojarov et al. (2004) studied the properties of CBH Ia and CBH IIa, which are classified to $\mathrm{GH} 7$ and GH6 family, respectively. $\mathrm{CBH}$ Ia is the product of MYCTH_109566 gene, and seems to be expressed in two isoforms with distinct molecular weights, one exhibiting the catalytic domain owing a CMB and the other only the catalytic domain and part of the linker, after proteolysis. This enzyme is produced as a major protein of fungi's secretome (20$25 \%$ of the total extracellular protein) and adsorbed strongly on microcrystalline cellulose. It has been shown that there is a significant synergism between $\mathrm{CBH}$ IIb and CBH Ia enzymes during substrate hydrolysis (Gusakov et al., 2007).

Recently, another type of specific activity was revealed. Xyloglucan specific exo- $\beta$-1,4-glucanase (Xgl74A; EC 3.2.1.155) is classified to GH74 family and catalyzes the hydrolysis of (1-4)-D-glucosidic linkages in xyloglucans aiming in the successful removal of oligosaccharides from the chain end (Grishutin et al., 2004). Xyloglucan is a major structural polysaccharide found in the primary cell walls of higher plants that interact with cellulose microfibrils via hydrogen bonds to form a structural network that is assumed to play a key role in cell wall integrity. It consists of a cellulose-like backbone of $\beta-1,4$ linked D-glucopyranose (D-Glcp) residues, which most of them are substituted at C-6 with $\alpha$-d-Xylp- $(1 \rightarrow 6)$ residues, to which other saccharides may be attached (most frequently, d-Galp and
1-Fucp). M. thermophila was found to produce an exo- $\beta-1,4$ glucanase (Xgl74A) (Grishutin et al., 2004) with high specific activity toward tamarind xyloglucan, and very low or absent activity against carboxymethylcellulose (CMC) and barley $\beta$ glucan. Due to its unique substrate specificity the enzyme was given a new number in the Enzyme Nomenclature (EC 3.2.1.155). Apart from Xgl74A, two out of the seven cellulases reported from M. thermophila (Cel12A and Cel45A) possess a notable activity against xyloglucan, together with their major activities toward CMC and barley $\beta$-glucan (Bukhtojarov et al., 2004).

\section{HEMICELLULOLYTIC SYSTEM}

Hemicellulose polymers have a much more diverse structure than cellulose and consequently several enzymes are needed to completely degrade the polysaccharide into monosaccharides. Xylan that is the major component of hemicellulose in the plant cell wall, is consisted of a $\beta$-D-(1,4)-linked xylopyranosyl backbone, which, depending on the origin, can be substituted with arabinofuranosyl, 4-0-methylglucopyranosyl, feruloyl and acetyl groups (Shibuya and Iwasaki, 1985). Feruloyl groups can form strong networks through peroxidase-catalyzed oxidative coupling forming diferuloyl bridges (Topakas et al., 2007). The main enzymes needed for depolymerization are xylanases, assisted by accessory enzymes such as $\beta$-xylosidases and different arabinofuranosidases making the xylan backbone more accessible (Sørensen et al., 2007). Other accessible enzymes that enhance xylan degradation are acetyl-xylanesterases (Poutanen et al., 1990), ferulic acid esterases (Topakas et al., 2007), and $\alpha$-glucuronidases (De Vries et al., 1998). M. thermophila's hemicellulase genes are organized in $10 \mathrm{GH}$ families $(3,10,11,30,43,51,62$, and 67) (Figure 2) and nine carbohydrate esterase (CE) families $(1,3,4,5,8,9$, 12, 15, and 16) (Figure 3). Many of the encoding proteins have been isolated from the WT culture supernatant or expressed in heterologous hosts and finally characterized in terms of specific

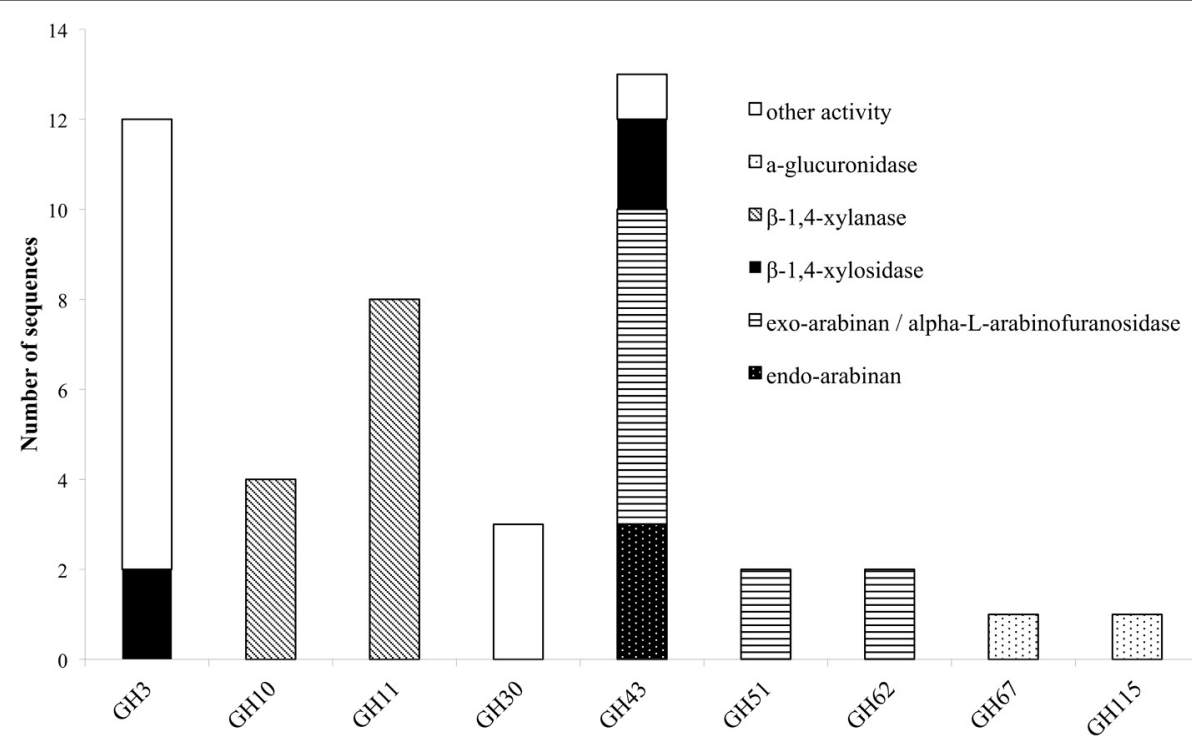

FIGURE 2 | Distribution of hemicellulolytic enzymes of $\boldsymbol{M}$. thermophila throughout nine GH families. Other activities refer to $\beta$-glycosidase (GH3), xylanase with endo-exo mode of action and xylobiohyrolase (GH30), and galactan 1,3-beta-galactosidase (GH43). 


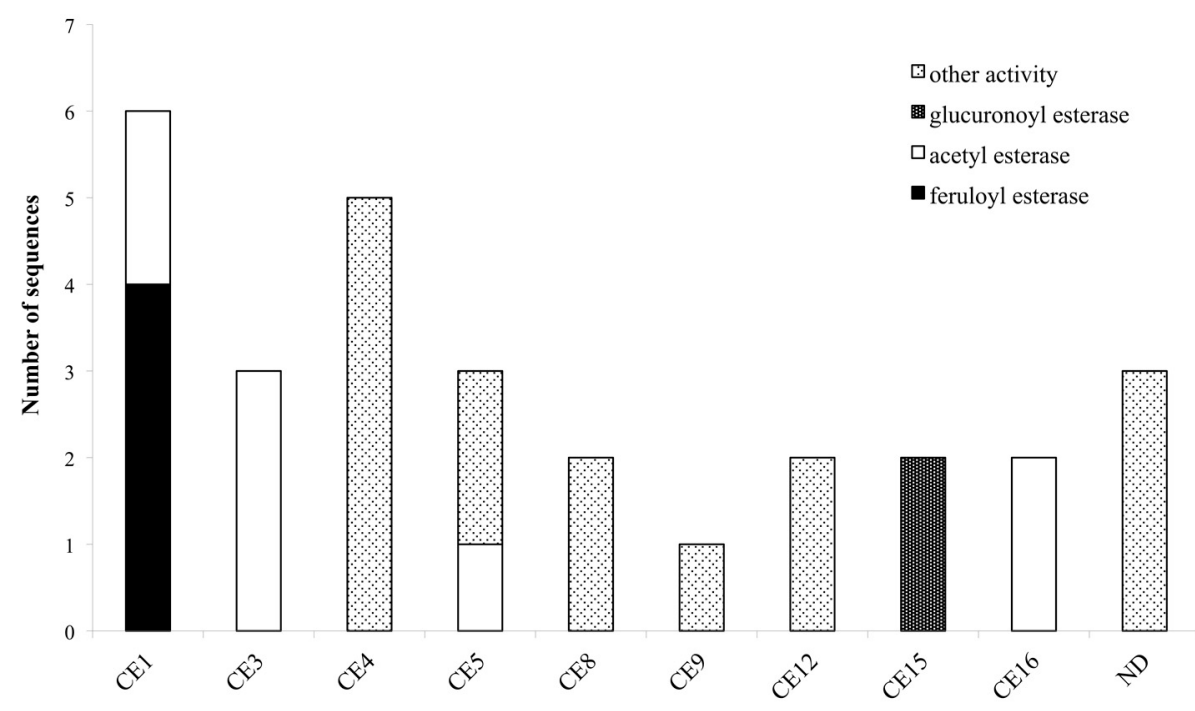

FIGURE 3 | Distribution of hemicellulolytic enzymes of $M$. thermophila throughout nine CE families. Family CE4 is comprised of putative proteins with polysaccharide deacetylase activity, CE5 of cutinases and
CE8, 12 of pectin esterases. ND (not determined) refers to sequences encoding putative proteins with unknown activity which are not classified to a specific family. activity and physicochemical properties. The majority of them are predicted to follow the secretion pathway, while modified with $\mathrm{N}$ and/or $O$-glucans, comprising a total amount of 66 enzymes that act synergistically for the degradation of hemicellulose.

\section{XYLANASES/XYLOSIDASES}

The degradation of xylan requires the concerted action of a number of powerful enzymes with varying specific activities, including xylanases and $\beta$-xylosidases. Xylanases (endo-1,4- $\beta$ xylanases, EC 3.2.1.8) are enzymes hydrolyzing $\beta$-1,4-glycosidic linkages in the backbone of xylans, while most of them belong to GH family 10 or 11 based on amino acid similarities and structural features (Henrissat, 1991). GH10 xylanases exhibit less substrate specificity than GH11 enzymes and can hydrolyze different types of decorated xylans, while GH11 xylanases are highly specific and do not tolerate many decorations on the xylan backbone (Biely et al., 1997). $\beta$-Xylosidases (EC 3.2.1.37) hydrolyze the soluble xylo-oligosaccharides and xylobiose from the non-reducing end liberating xylose, produced by the activity of xylanases. These enzymes play an important role in xylan degradation by relieving the end product inhibition of endoxylanases (Knob et al., 2010). The genome of M. thermophila encodes totally 12 xylanases with endo- mode of activity, classified to GH 10 and 11 and four xylosidases, classified to GH3 and 43 families (Table 4). All aforementioned xylan-degrading translated sequences, apart from three, are predicted to exhibit a potential secretion signal. Xylanases possess 1-3 N-glycosylation and several $O$-glycosylation sites, whereas more $N$-sites are predicted for xylosidases, though not all of them are glycosylated during post-translational modifications. GH family 30 contains two genes encoding xylanolytic enzymes with endo-exo activity and one sequence for a characterized xylobiohydrolase, releasing xylobiose units from the substrate (Emalfarb et al., 2012).
Ten xylanases have been purified and characterized from multienzyme preparations of $M$. thermophila modified strains (Ustinov et al., 2008; van Gool et al., 2013). Four of them, belonging to GH10 family (Table 5), are the products of two genes, either with the presence of a family $1 \mathrm{CBM}$ or displaying only the catalytic domain after partial proteolytic digestion (Ustinov et al., 2008). These enzymes, thought classified to the same family, can hydrolyze different types of decorated xylans. They differ in degradation of high and low substituted substrates and the substitution pattern seems to be an important factor influencing their efficiency (van Gool et al., 2012). Six xylanases, belonging to GH11 family, represent true xylanases, with high specific activities against glucuronoxylans and arabinoxylans. Four of these enzymes exhibit lower thermostability in comparison to GH10 xylanases, in which extended glycosylation has been noticed (Ustinov et al., 2008). One showed a substrate specificity pattern similar to GH10 enzymes and secreted in two forms, with or without CBM (van Gool et al., 2013).

\section{ARABINOHYDROLASES}

$\mathrm{L}$-arabinose is widely present in various hemicellulosic biomass components, such as arabinoxylan, where the main $\beta$-D- $(1,4)$ linked xylopyranosyl backbone is substituted with arabinose residues. $\alpha$-L-arabinofuranosidases (AFase; EC 3.2.1.55) are enzymes that release arabinofuranose residues substituted at position $\mathrm{O}-2$ or $\mathrm{O}-3$ of mono or di-substituted xylose residues (Gruppen et al., 1993). Apart from that, AFases act in synergism with other arabinohydrolases, endo- $(1,5)-\alpha$-L-arabinanases (ABNase; EC 3.2.1.99) for the decomposition of arabinan, a major pectin polysaccharide. Arabinan consists of a backbone of $\alpha$-(1,5)-linked L-arabinofuranosyl residues, some of which are substituted with $\alpha$-(1,2)- or $\alpha$-(1,3)-linked arabinofuranosides (Weinstein and Albersheim, 1979). Degradation of arabinan polymer to arabinose sugars is driven by the synergistic action of 


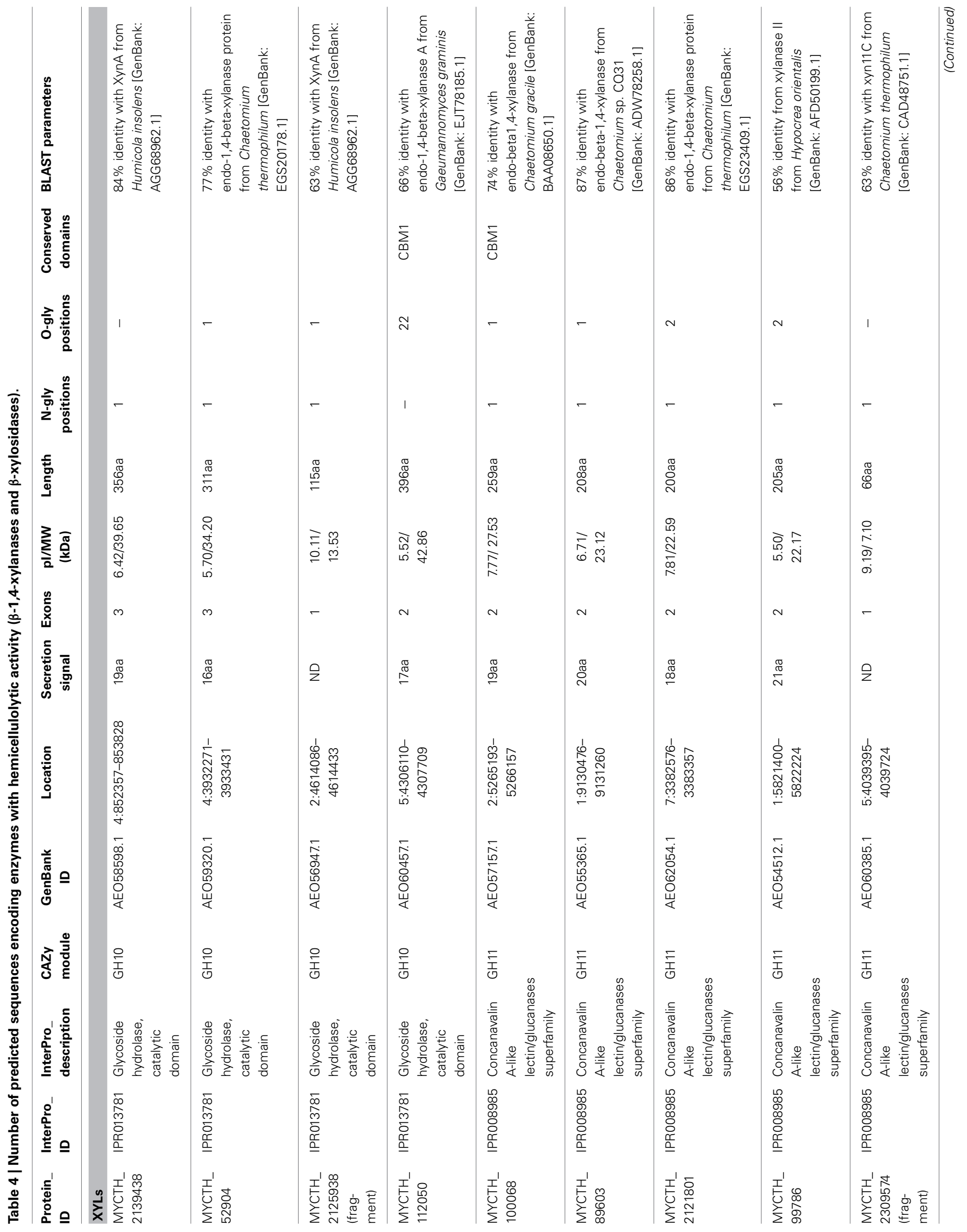




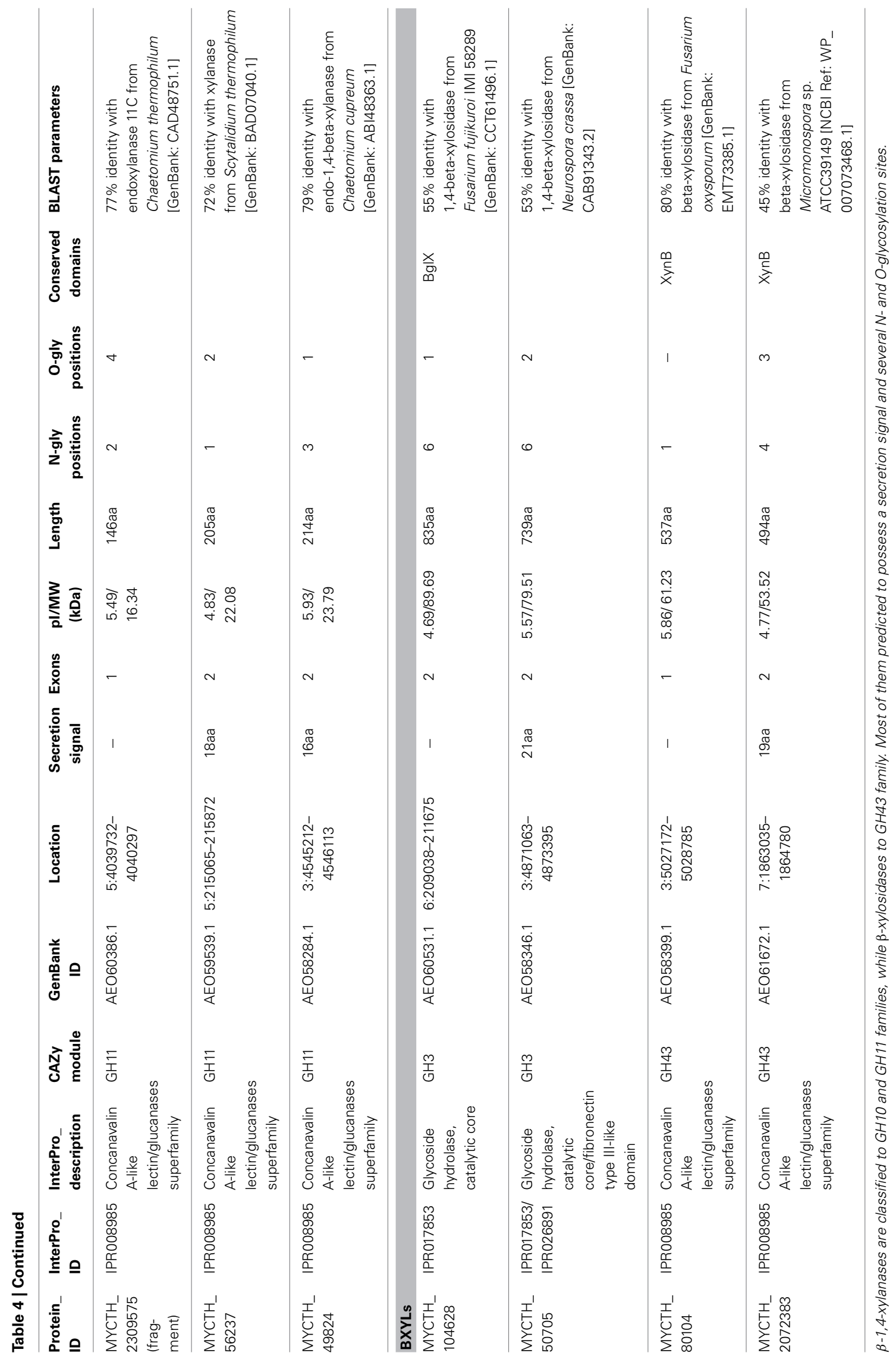


Table 5 | Description of the characterized $\beta-1,4-x y l a n a s e s$ isolated from the culture broth of a M. thermophila C1 mutant strain.

\begin{tabular}{|c|c|c|c|c|c|c|c|}
\hline Enzyme & CAZy module & MW-monomer (kDa) & $\mathrm{pH}_{\mathrm{opt}}$ & $\mathrm{T}_{\text {opt }}\left({ }^{\circ} \mathrm{C}\right)$ & pl & Gene & References \\
\hline Xyn10A & $\mathrm{GH} 10$ & $42 / 31^{*}$ & $5.5-7.0$ & $65-70$ & $7.8 / 8.9$ & $x y / 1$ & Ustinov et al., 2008; van Gool et al., 2012 \\
\hline Xyn10B & $\mathrm{GH} 10$ & $57 / 46^{*}$ & $5.5-7.0$ & $80-85$ & $4.4 / 4.3$ & $x y / 3$ & Ustinov et al., 2008; van Gool et al., 2012 \\
\hline Xyn11A & $\mathrm{GH} 11$ & 24 & 6.5 & 70 & 7.9 & $x y / 2$ & Ustinov et al., 2008 \\
\hline Xyn11B & $\mathrm{GH} 11$ & 23 & $6.0-6.5$ & $65-70$ & 8.4 & $x y / 6$ & Ustinov et al., 2008 \\
\hline Xyl8 & $\mathrm{GH} 11$ & 22 & $5.5-6.0$ & $50-65$ & 6.2 & $x y / 8$ & van Gool et al., 2013 \\
\hline
\end{tabular}

They display optimal activity at temperatures between 50 and $70^{\circ} \mathrm{C}$, increasing fungi's hydrolytic efficiency in various temperatures. Marked proteins $\left({ }^{*}\right)$ were isolated in two different forms, with (high molecular weight enzyme) or without CBM (low molecular weight enzyme).

two major enzymes, AFases and ABNases (Kim, 2008). AFases specifically catalyze the hydrolysis of terminal non-reducing L-arabinofuranosyl residues from arabinan, while the resulting debranched backbone could be efficiently hydrolyzed by endo-acting ABNases, thus generating a variety of arabinooligosaccharides with an inverting mode of action (Beldman et al., 1997). Thoughout CAZy families, arabinohydrolases belong to the GH family 43, 51, 54, 62, and 93 (Figure 3 ).

The genome of the $M$. thermophila encodes 14 enzymes that putatively release arabinose or arabinose oligomers from arabinan (Hinz et al., 2009). Eleven sequences contain a secretion signal peptide and produced as extracellular or cell-bounded proteins, while almost all of them exhibit isoelectric point around 4.65.6 (Table 6). Seven of them have been selectively overexpressed homologously in M. thermophila $\mathrm{C} 1$ host and found to release arabinose from wheat arabinoxylan polymers and oligomers (Hinz et al., 2009). M. thermophila arabinofuranosidases are selective in releasing arabinose from either single or double substituted xylose residues in arabinoxylans. Eight enzymes, belonging to GH families $43,51,62$, and 93 with different type of arabinolytic activity have been purified and characterized (Hinz et al., 2009; Kühnel et al., 2011; Pouvreau et al., 2011b) (Table 7).

Abn7 and Abf3 are GH43 and GH51 arabinases respectively, which were selectively produced in $\mathrm{C} 1$ host. Abn7 was found to hydrolyze arabinofuranosyl residues at position O-3 of double substituted xylosyl residues in arabinoxylan-derived oligosaccharides, while Abf3 released arabinose from position $O-2$ or $O-3$ of single substituted xyloses. When these enzymes were incubated together, in combination with a GH10 endoxylanase for the hydrolysis of arabinoxylans, they resulted in a synergistic increase in arabinose release from the substrate (Pouvreau et al., 2011b). In addition, a-L-arabinohydrolases Abn1, Abn2, and Abn4 were overexpressed in $\mathrm{C} 1$ and the produced culture supernatant has been shown to produce neutral branched arabino-oligosaccharides from sugar beet arabinan by enzymatic degradation. As found by sugar analysis, neutral arabino-oligosaccharides contained an $\alpha-(1,5)$-linked backbone of l-arabinosyl residues and carried single substituted $\alpha-(1,3)$ linked l-arabinosyl residues or consisted of a double substituted $\alpha-(1,2,3,5)$-linked arabinan structure within the molecule (Westphal et al., 2010). Enzyme Abn4 belongs to GH43 family and is more active toward branched polymeric arabinan substrate that releases arabinose monomers from single substituted arabinose residues, while Abn1 and Abn2 are active toward linear arabinan (Kühnel et al., 2010). Abn2 is a member of GH93 family that consists of exoarabinases acting on linear arabinan, hydrolyzing the $\alpha-1,5$-linkages of arabinan polysaccharides presented as side chains of pectin. Their mode of action was studied with Abn2, which binds two arabinose units at the subsites -1 and -2 and releases arabinose. Three more arabinohydrolases were also overexpressed in C1 strain (Hinz et al., 2009). Abn5 was found to be specifically active toward arabinan, but not arabinoxylan. Arabinofuranosidases Abf1 and Abf2, members of GH62 family released $O-2$ or $O-3$ substituted arabinose or linked arabinofuranosyl from mono substituted xylose. GH family 62 arabinofuranosidases are reported to be predominantly active toward arabinoxylan and are, therefore, also called arabinoxylan arabinofuranohydrolases (Beldman et al., 1997). Several of these enzymes contain either a CBM1, like Abf1, or a CBM43 (xylan)-binding domain.

\section{ESTERASES}

The role of esterases in the breakdown of lignocellulosic material is complex and includes the cleavage of bonds between the main hemicellulose part and many types of side chains. So, upon a closer examination of the genome sequences of $M$. thermophila, there is a wide distribution of enzymatic activities through CE families. These enzymes are classified into nine families and their main activities, among others, include the hydrolysis of feruloyl and acetyl ester bonds.

Feruloyl esterases (FAEs; EC 3.1.1.73) are enzymes responsible for cleaving the ester-link between the polysaccharide main chain of xylans and monomeric or dimeric ferulates. They act synergistically with xylanases to release ferulic acid from cellwall material and can be divided into four groups, namely A-D. The main difference between groups $\mathrm{A}$ and $\mathrm{D}$ is their substrate specificity toward synthetic substrates and their capability of liberating diferuloyl bridges (Crepin et al., 2004). One of the first FAEs reported from thermophilic fungi, was produced from M. thermophila under solid-state fermentation (SSF) conditions. The esterase activity was isolated and partially characterized for its ability to release ferulic acid from complex substrate, destarched wheat bran (Topakas et al., 2003). Two other FAEs, StFaeB, a protein with molecular weight of $66 \mathrm{kDa}$ 


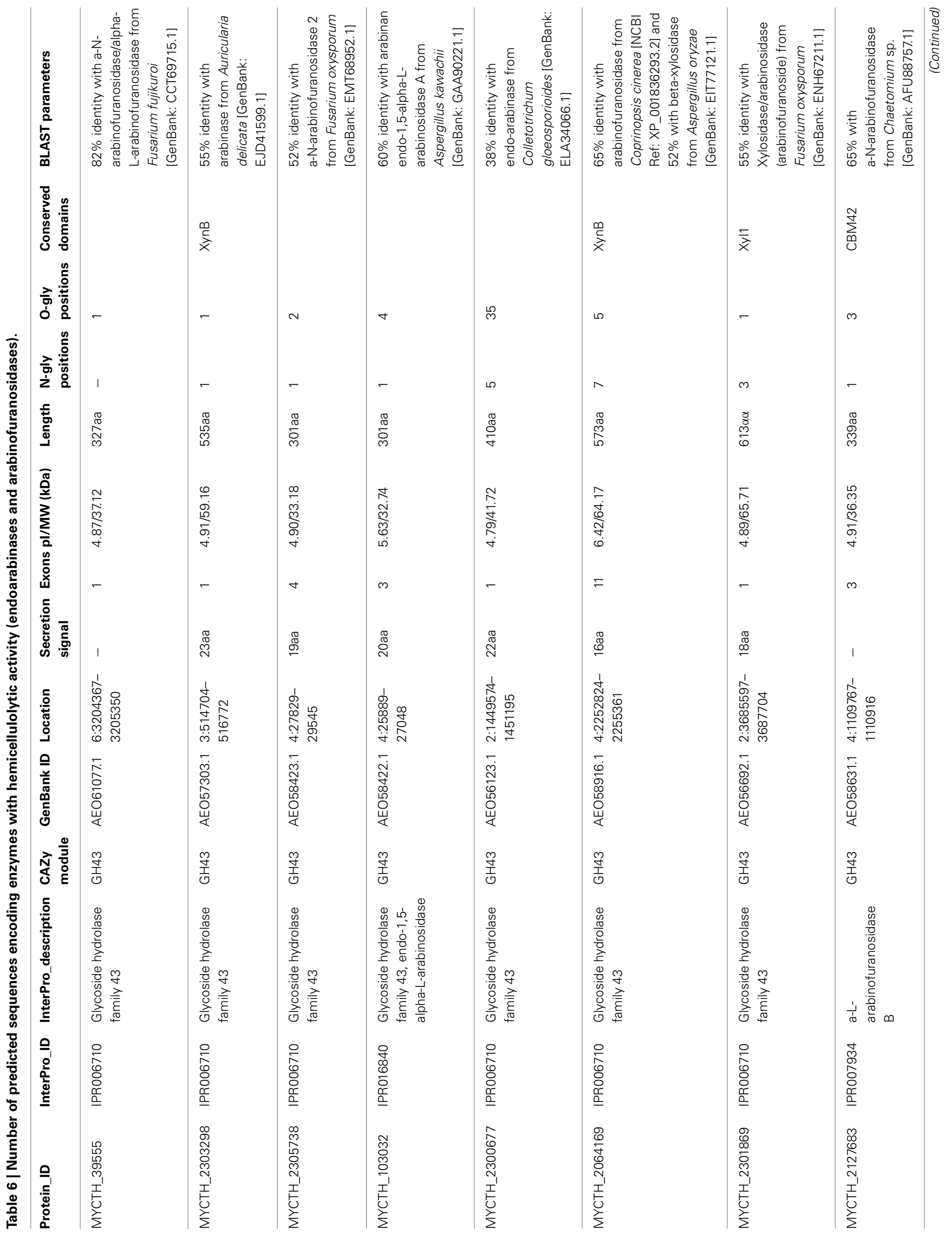




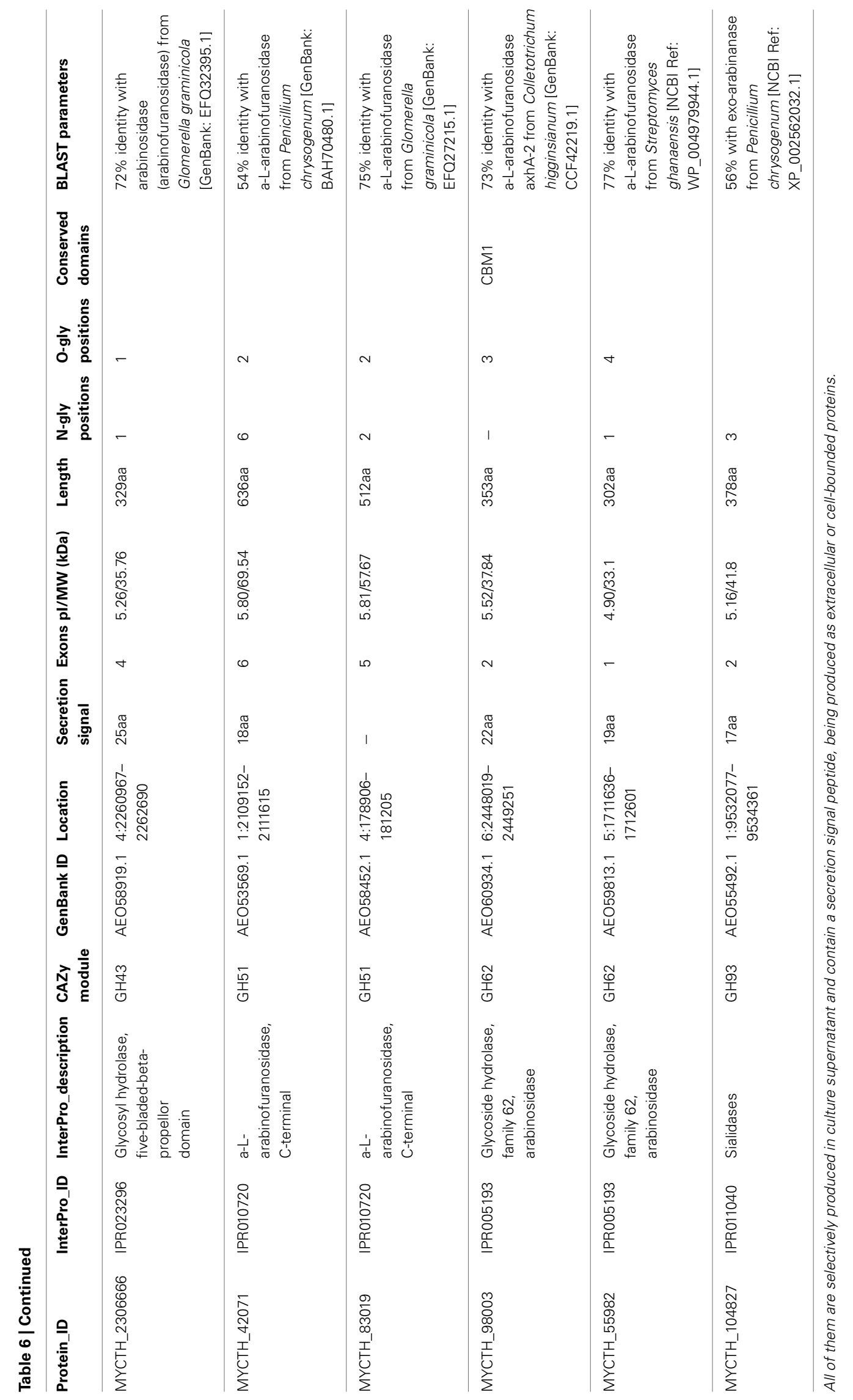


Table 7 | Description of the characterized endoarabinases and arabinofuranosidases isolated from the culture broth of a $M$. thermophila $\mathrm{C1}$ mutant strain.

\begin{tabular}{|c|c|c|c|c|c|c|c|c|c|}
\hline Enzyme & $\begin{array}{l}\text { CAZy } \\
\text { module }\end{array}$ & Mode of action & $\begin{array}{l}\text { MW- } \\
\text { monomer } \\
\text { (kDa) }\end{array}$ & $\mathrm{pH}_{\mathrm{opt}}$ & $\begin{array}{l}\mathrm{T}_{\text {opt }} \\
\left({ }^{\circ} \mathrm{C}\right)\end{array}$ & $\begin{array}{l}\text { Uniprot/ } \\
\text { SwissProt } \\
\text { ID }\end{array}$ & Gene & Source & References \\
\hline Abf2 & GH62 & $\begin{array}{l}\text { Arabinofuranosidase/ } \\
\text { releases O-2 or O-3 } \\
\text { linked } \\
\text { arabinofuranosyl } \\
\text { residues from } \\
\text { mono-substituted } \\
\text { xylose }\end{array}$ & & & & & $a b f 2$ & $\begin{array}{l}\text { Selectively } \\
\text { produced in } \\
\text { C1-host }\end{array}$ & Hinz et al., 2009 \\
\hline Abn7 & $\mathrm{GH} 43$ & $\begin{array}{l}\text { Arabinofuranosidase/ } \\
\text { releases O-3 linked } \\
\text { arabinofuranosyl } \\
\text { residues from } \\
\text { di-substituted xylose }\end{array}$ & 70 & 5 & 40 & HO324255 & $a b n 7$ & $\begin{array}{l}\text { Selectively } \\
\text { produced in } \\
\text { C1-host }\end{array}$ & Pouvreau et al., 2011b \\
\hline Abn1 & $\mathrm{GH} 43$ & Endoarabinase & 36 & 5.5 & 60 & HO324251 & $a b n 1$ & $\begin{array}{l}\text { Overexpressed } \\
\text { in fermentation } \\
\text { supernatant }\end{array}$ & Kühnel et al., 2011 \\
\hline Abn4 & $\mathrm{GH} 43$ & $\begin{array}{l}\text { Arabinofuranosidase/ } \\
\text { releases arabinose } \\
\text { from the } \\
\text { non-reducing end of } \\
\text { reduced arabinose } \\
\text { oligomers }\end{array}$ & 33 & 5.5 & 60 & HO324253 & $a b n 4$ & $\begin{array}{l}\text { Overexpressed } \\
\text { in fermentation } \\
\text { supernatant }\end{array}$ & Kühnel et al., 2011 \\
\hline Abn5 & & Arabinofuranosidase & & & & & $a b n 5$ & $\begin{array}{l}\text { Selectively } \\
\text { produced in } \\
\text { C1-host }\end{array}$ & Hinz et al., 2009 \\
\hline
\end{tabular}

(homodimers of $33 \mathrm{kDa}$ ) (Topakas et al., 2004) and StFaeC, $46 \mathrm{kDa}$ (homodimers of $23 \mathrm{kDa}$ ) (Topakas et al., 2005), were purified to homogeneity from culture supernatants of $M$. thermophila. StFaeB hydrolyzed methyl $p$-coumarate, methyl caffeate and methyl ferulate and was active on substrates containing ferulic acid ester linked to the C-5 and C-2 linkages of arabinofuranose. StFaeC showed maximum catalytic efficiency on 4-hydroxy-3-methoxy cinnamate, a substrate with both hydroxyl and methoxy substituents, indicating that it may be the most promising type of FAE as a biocatalyst for the enzymatic feruloylation of aliphatic alcohols, oligo- and polysaccharides. Properties of characterized FAEs are summarized in Table 8. Among the sequences registered to Genome Portal, there are four sequences encoding proteins with catalytic activity of FAE, all belonging to CE family 1 . Two of them (MYCTH_48379, MYCTH_39279) seem to be identical with characterized FAEs secreted from $M$. 
Table 8 | Description of $M$. thermophila characterized esterases (FAEs, AcEs, and GEs).

\begin{tabular}{|c|c|c|c|c|c|c|c|c|}
\hline Enzyme & Type & MW-monomer (kDa) & $\mathrm{pH}_{\text {opt }}$ & $\mathrm{T}_{\text {opt }}\left({ }^{\circ} \mathrm{C}\right)$ & pl & Gene & Source & References \\
\hline \multicolumn{9}{|l|}{ FAEs } \\
\hline StFaeB & B & $33^{*}$ & 6 & $55-60$ & 3.5 & & Isolated from culture supernatant & Topakas et al., 2004 \\
\hline StFaeC & $\mathrm{C}$ & $23^{*}$ & 6 & 55 & $<3.5$ & & Isolated from culture supernatant & Topakas et al., 2005 \\
\hline FAE & ND & 27 & 8 & 60 & 5 & & Isolated from culture supernatant & Topakas et al., 2003 \\
\hline FaeA1 & $A$ & 29 & 6.5 & 45 & $\approx 5.5$ & & Overexpressed in fermentation supernatant & Kühnel et al., 2012 \\
\hline FaeA2 & A & 36 & 7.5 & 40 & $\approx 5.2$ & & Overexpressed in fermentation supernatant & Kühnel et al., 2012 \\
\hline FaeB2 & $\mathrm{B}$ & 33 & 7.5 & 45 & $\approx 6.0$ & & Overexpressed in fermentation supernatant & Kühnel et al., 2012 \\
\hline MtFae1a & $\mathrm{B}$ & 39 & 7 & 50 & ND & faela & Expressed in P. pastoris & Topakas et al., 2012 \\
\hline \multicolumn{9}{|l|}{ AcEs } \\
\hline MtAxe3 & 1 & 33.6 & 7 & 40 & ND & axe3 & Overexpressed in fermentation supernatant & Pouvreau et al., 2011a \\
\hline MtAxe2 & 5 & 23.6 & 7 & 40 & ND & axe2 & Overexpressed in fermentation supernatant & Pouvreau et al., 2011a \\
\hline \multicolumn{9}{|c|}{ 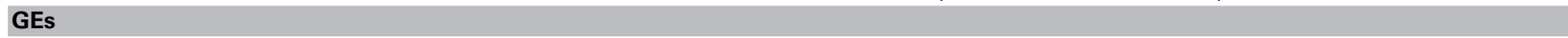 } \\
\hline StGE2 & 15 & 43 & 7 & 55 & ND & ge2 & Expressed in P. pastoris & Topakas et al., 2010 \\
\hline StGE1 & 15 & 58 & 6 & 60 & ND & & Isolated from culture supernatant & Vafiadi et al., 2009 \\
\hline
\end{tabular}

${ }^{*}$ All proteins are monomeric, while in case of FaeB2, dimeric structures are detected, after comparing the results of SDS-PAGE and native electrophoresis.

thermophila C1 strain (Kühnel et al., 2012). One sequence (JDI ID: 96478) has been heterologously expressed in P. pastoris and encoded a $39 \mathrm{kDa}$ protein (faelA; MtFaela), which showed high activity toward methyl caffeate and p-coumarate and a strong preference for the hydrolysis of n-butyl and iso-butyl ferulate (Topakas et al., 2012). In addition, MtFael esterase release ferulic acid from destarched wheat bran only by the synergistic action of an endo-xylanase (a maximum of $41 \%$ total ferulic acid released after $1 \mathrm{~h}$ incubation). MYCTH_2302953 sequence has not yet been characterized, however it still shows $66 \%$ identity with a type B FAE from Neurospora crassa (CAC05587.1). All proteins encoded by the above sequences appear to be secreted and bring several $\mathrm{N}$ - and $\mathrm{O}$-glycosylation sites, as shown in Table 9.

About $60-70 \%$ of the xylose residues in hardwood xylan are acetylated at the $\mathrm{C} 2$ and/or C3 positions (Lindberg et al., 1973). The complete degradation of acetylated xylans by microbes requires the action of acetyl esterases (AcEs; EC 3.1.1.72), which cleave acetyl side groups from the heteroxylan backbone, and act in synergy with other hemicellulases (Tenkanen et al., 1996). Eight sequences that encode proteins with AcE activity were detected in the genome of $M$. thermophila and showed identity with characterized enzymes. All of them are secreted, as predicted with SignalP and belong to CE families 1, 3, 5, 16 (Table 9). Two of them, Axe2 and Axe3, which bare members of CE5 and CE1 families, respectively, were isolated and characterized (Pouvreau et al., 2011a). Annotated genes, encoding the putative enzymes were cloned into the specially designed $M$. thermophila C1-expression host (Verdoes et al., 2010) and over-produced in the culture medium. Axe2 and Axe3 are able to hydrolyze acetyl groups when they are substituted to the $\mathrm{O}-2$ and $\mathrm{O}-3$ positions of acetylated xylo-oligosaccharides and complex insoluble polymeric substrates and had a preference for xylooligosaccharides (Pouvreau et al., 2011a).

Glucuronoyl esterases (GEs) are recently discovered enzymes that are suggested to play an important role in the dissociation of lignin from hemicellulose and cellulose by cleaving the ester bonds between the aromatic alcohols of lignin and the carboxyl groups of 4-O-methyl-D-glucuronic acid residues in glucuronoxylan (Špániková and Biely, 2006). Sequence alignment studies of these enzymes have revealed a novel conserved amino acid sequence G-C-S-R-X-G that features the characteristic serine residue involved in the mechanism of this esterase family. It has been shown that the mode of action probably involves a nucleophilic serine (Topakas et al., 2010). The genome of M. thermophila possesses two genes classified to family CE15 that encode proteins with activity of 4-O-methyl-glucuronoyl esterase. Both putative enzymes are secreted and have potential glycosylation sites. The first GE (StEG1), isolated from the culture filtrate of M. thermophila, was proved to be a thermophilic enzyme that presents a C-terminal CBM, which was active on substrates containing glucuronic acid methyl ester (Vafiadi et al., 2009). Another CE15 protein molecule, StGE2 was heterologously expressed in yeast $P$. pastoris and was used to prove that nucleophilic serine residue is responsible for catalytic action of GEs, through sitedirected mutagenesis studies (Topakas et al., 2010) and crystal structure determination (Charavgi et al., 2013).

\section{MANNAN-DEGRADING ENZYMES}

Mannan is a great component of hemicellulose, therefore, as expected, the lignocellulolytic toolbox of M. thermophila possesses a complete reservoir of genes encoding mannan degrading enzymes. Mannan polymer primarily consists of a backbone structure composed of $\beta$-1,4-bound mannose residues or combination of glucose and mannose residues and can be hydrolyzed to its monomers with the synergistic action of $\beta$-mannanases (EC 3.2.1.78), $\beta$-mannosidases (EC 3.2.1.25), $\alpha$-galactosidases (EC 3.2.1.22), and acetylmannan esterases (E.C. 3.1.1.6) (McCleary, 1988). The genome of $M$. thermophila encodes three enzymes that putatively catalyze random cleavage of the mannan polysaccharide and belong to GH family 5 and 26 . One of these enzymes has been isolated from culture supernatant, characterized and classified as GH5 endo- $\beta$-1,4-mannosidase (bMan2, Dotsenko et al., 2012). In addition, there are two genes encoding putative $\beta$ mannosidases belonging to $\mathrm{GH} 2$ family, while one of them has been characterized in terms of its specificity and physicochemical 


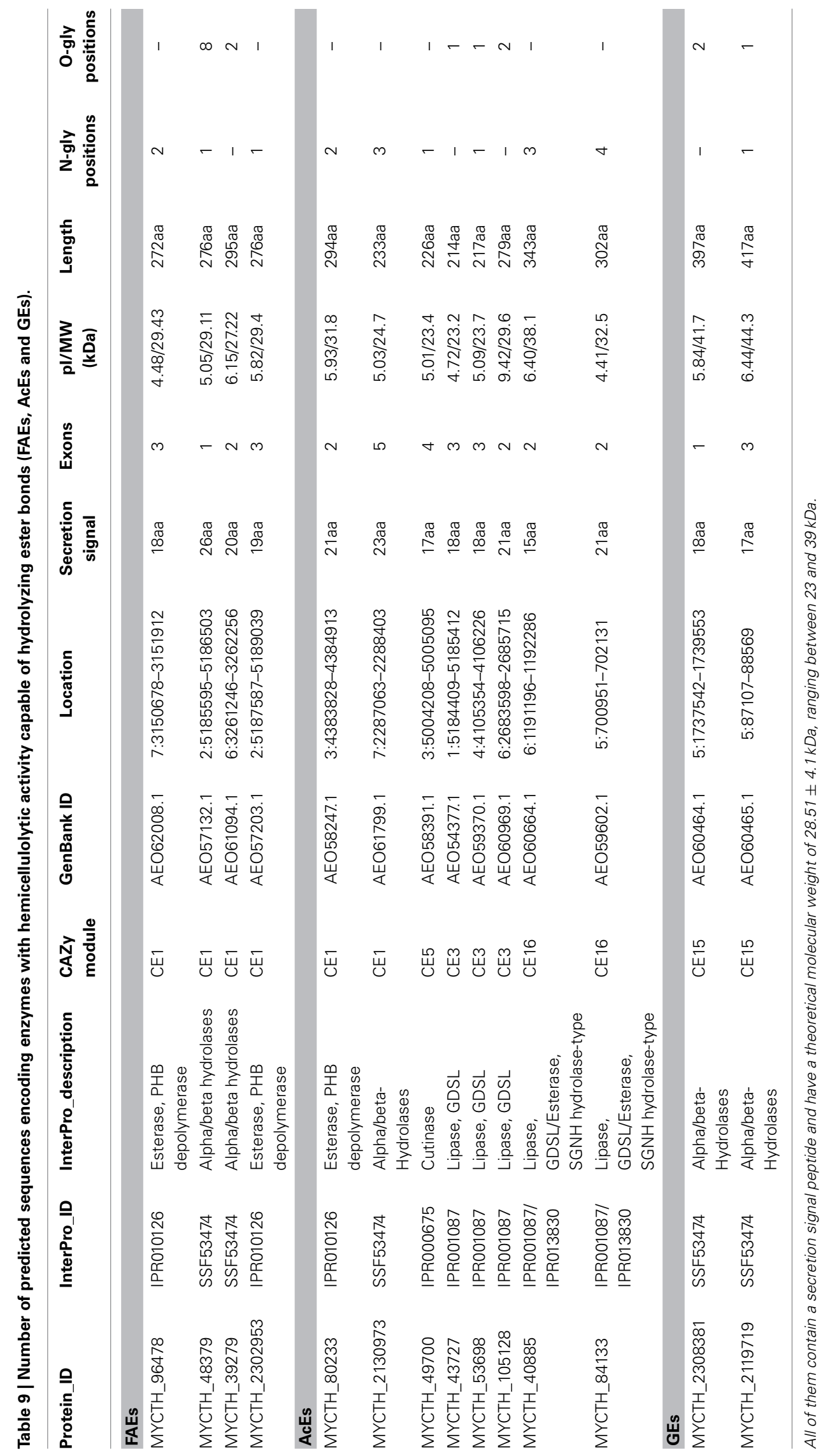


properties (bMann9, Dotsenko et al., 2012). Two GH27 and one GH26 $\alpha$-galactosidases boost the efficiency of fungal culture supernatant against hydrolysis of mannan substrate (Emalfarb et al., 2012), while two CE12 family genes encoding proteins with high similarity to known acetyl-mannan esterases have been found.

\section{AUXILIARY ENZYMES}

In spite of the cooperative activity exhibited by the cellulolytic and hemicellulolytic enzymes, the impressive hydrolytic ability of various microorganisms in nature cannot be attributed only to this endo-exo mechanism. Apart from the hydrolytic system responsible for carbohydrate degradation, it seems that an oxidative system catalyze lignin depolymerization and oxidation of plant cell wall components, yielding reactive molecules (e.g., $\mathrm{H}_{2} \mathrm{O}_{2}$ ). Recent evidence highlights the critical role of alternative enzymatic partners involved in the oxidation of cell wall components. Among these enzymes, outstanding role during hydrolysis exhibit the originally described as cellulases LPMO enzymes, $\mathrm{CDH}$ and multicopper enzymes such as laccases. The genome of M. thermophila possesses more than 30 genes that encode proteins with such auxiliary activities (Figure 4). Members of the LPMO family AA9, have been shown to be copper-dependent monooxygenases that enhance cellulose degradation in concert with classical cellulases, as aforementioned before and reviewed by Dimarogona et al. (2013). These enzymes catalyze the cleavage of cellulose by an oxidative mechanism provided that reduction equivalents are available. These equivalents either involve low molecular weight reducing agents (e.g., ascorbate) or are produced by $\mathrm{CDH}$ activity (Langston et al., 2011). CDHs are extracellular enzymes produced by various wood-degrading fungi that oxidize soluble cellodextrins, mannodextrins and lactose efficiently to their corresponding lactones by a ping-pong mechanism using a wide spectrum of electron acceptors (Henriksson et al., 2000). Throughout the genome of M. thermophila, two genes encoding proteins classified to AA 3 and 8 families have been identified (Figure 4). Both of them are predicted to be secreted in the culture supernatant and have potential glycosylation sites. The translated CDH MYCTH_111388 exhibits a C-terminal CBM and a cDNA clone of this sequence has been isolated and biochemically characterized by screening an expression library of M. thermophila (Subramaniam et al., 1999). Canevascini et al. (1991) purified a monomeric $(91 \mathrm{kDa})$ and a dimeric $(192 \mathrm{kDa})$ form of $\mathrm{CDH}$ that differed not only in molecular weight, but amino acid composition and carbohydrate content. Both forms oxidized cellobiose in the presence of cytochrome $\mathrm{c}$ or dichlorophenol-indophenol.

Laccases (EC 1.10.3.1) are multicopper enzymes that catalyze the oxidation of a variety of phenolic compounds, with concomitant reduction of $\mathrm{O}_{2}$ to $\mathrm{H}_{2} \mathrm{O}$. These polyphenol oxidases are produced by most ligninolytic basidiomycetes (Baldrian, 2006) and can degrade lignin and other recalcitrant compounds in the presence of redox mediators (Ruiz-Dueñas and Martínez, 2009). The genome of the $M$. thermophila encodes eight putative enzymes with multicopper oxidase activity. Four of them have been annotated and one (MYCTH_51627) matches the lccl gene product encoding an extracellular laccase (Berka et al., 1997).

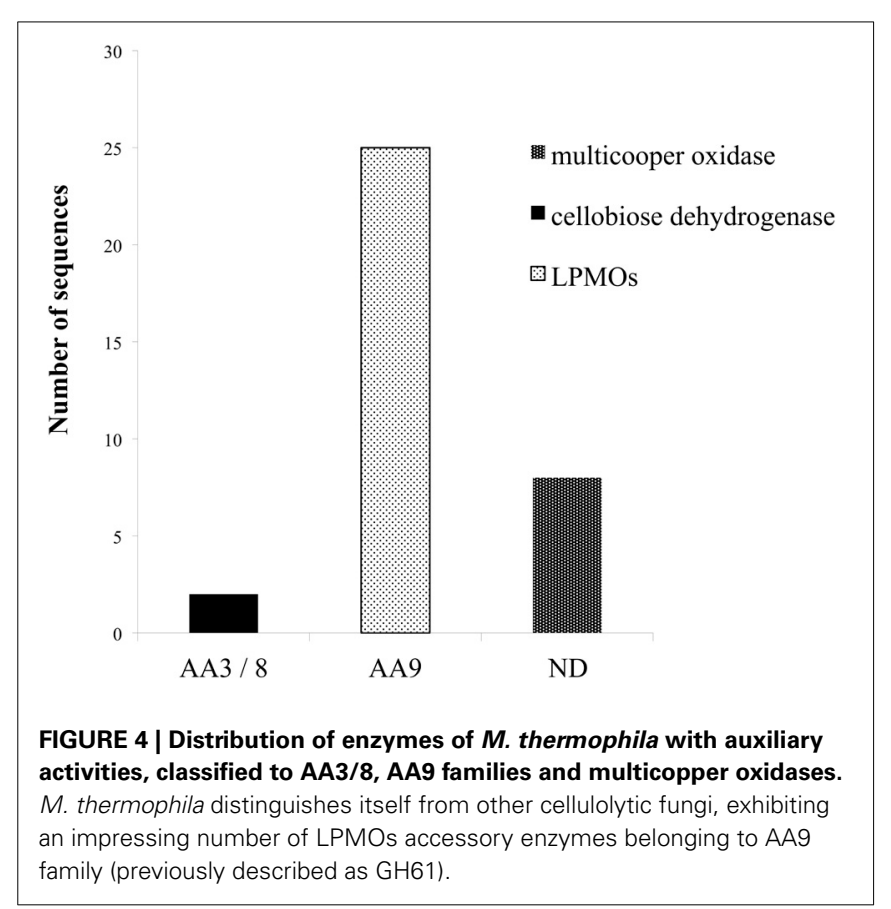

Four sequences are predicted to possess a secretion signal, while one appears to remain membrane-bound. $L c c 1$ gene has been isolated from fungi's genome, heterologously expressed in A. oryzae and the produced $85 \mathrm{kDa}$ enzyme $(\mathrm{MtL})$ was characterized as a thermostable low oxidation potential laccase with high reactivity in aqueous medium at room temperature and neutral $\mathrm{pH}$. MtL was tested for its capacity to catalyze enzymatic oxidation of several phenolic and polyphenolic compounds (ferulic acid, gallic acid, caffeic acid, and catechin) (Mustafa et al., 2005). M. thermophila laccases have been reported to oxidize lignin surface, by increasing the amount of radicals during thermomechanical pulp fiber material bleaching (Grönqvist et al., 2003) and promote oxidative polymerization of Kraft lignin from back liquor, which is the main by-product of pulp and paper industry (Gouveia et al., 2013).

\section{LIGNOCELLULOSIC POTENTIAL-STATISTICS}

M. thermophila is a powerful lignocellulolytic organism, which secretes a complex system of carbohydrate hydrolases for the breakdown of cellulose and hemicellulose, as well as oxidoreductases embedded in lignin degradation. Genome analysis in this review revealed 30 genes encoding cellulases classified to 10 $\mathrm{GH}$ families, 66 genes encoding hemicellulases classified to 10 GHs, 9 CEs and 35 genes encoding auxiliary enzymes. The latter include CDHs (AA3/AA8 family), LPMOs (AA9 family) and multicopper oxidases (laccases or laccase-like enzymes). Out of the total consortium of $M$. thermophila sequences encoding proteins with putative lignocellulosic activity, $80.2 \%$ are predicted to have a secretion signal peptide. Almost $76 \%$ of cellulases, hemicellulases and $88 \%$ of the accessory redox enzymes are targeted to secretion pathway, while only a very small amount remain inside the cell or represent membrane cell-bound macromolecules. Only $15.8 \%$ of the secreted enzymes in this 


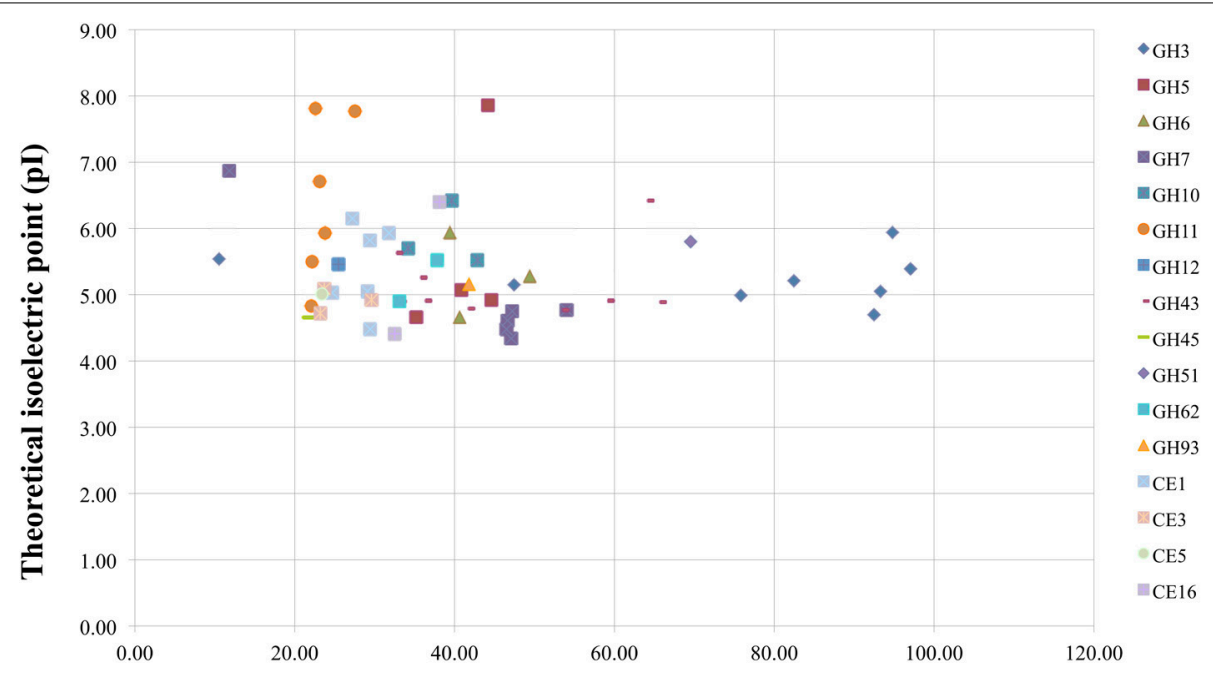

Theoretical molecular weight $(\mathrm{kDa})$

FIGURE 5 | Theoretical molecular weight of secreted enzymes of $\boldsymbol{M}$. thermophila classified in several GHs and CEs families, plotted against theoretical pl. The average molecular weight was calculated at $51.05 \pm$
16.2 kDa (range between 21 and $97 \mathrm{kDa}$ ) for cellulolytic enzymes, $35.5 \pm$ $19.5 \mathrm{kDa}$ (range between 22 and $89 \mathrm{kDa}$ ) for hemicellulases (GHs/CEs), and $28.51 \pm 4.1 \mathrm{kDa}$ (range between 23 and $39 \mathrm{kDa}$ ) for the fraction of esterases. review are predicted to possess a CBM and the majority of them comprise of auxiliary enzyme activities. The theoretical average molecular weight of secreted enzymes is $41.36 \pm 15.9$, varying between 10 and $97 \mathrm{kDa}$. The majority of secreted enzymes have molecular weight varying between 20 and $50 \mathrm{kDa}$, whereas $\beta$-xylosidases and $\beta$-glycosidases (GH3 family), and arabinofuranosidases (GH43 and GH51) appear to be high molecular weight proteins (Figure 5). The theoretical average isoelectric point of secretory enzymes is calculated $5.27 \pm 0.8$, at a range 4.34-7.9. In vivo expression and study of these enzymes would give different results, as the proteins are glycosylated, so size and pI value tend to moderate.

\section{PROTEIN GLYCOSYLATION}

A total proportion of $92.8 \%$ of secreted proteins have either $N$ or $O$ - putative glycosylation sites. These proteins are often glycosylated due to the existence of many Asn-Xaa-Ser/Thr sequons, which are known to be a prerequisite for $N$-glycosylation posttranslational modifications. The molecules of many GHs and accessory enzymes have a modular structure consisting of a catalytic module, flexible peptide linker, and CBM. Flexible linker peptides, which are rich in Ser and Thr residues, are typically $O$-glycosylated (Gilkes et al., 1991). The $N$-glycosylation seems to be restricted to the catalytic modules, and it is usually absent in other parts of enzyme molecules. Various $N$-linked glycan structures have been found in different enzymes from $M$. thermophila, belonging to different enzyme classes and protein families (Gusakov et al., 2008). It has been noticed that glycosylation follows a heterogeneity pattern, meaning that in some molecules, the same Asn residue was modified with oligosaccharides having different structure, while not all of the potential glycosylation sites were found to be occupied. The most frequently met $N$ linked glycan was $(\mathrm{Man})_{3}(\mathrm{GlcNAc})_{2}$, a pentasaccharide which represents a well-known conserved core structure that forms mammalian-type high-mannose and hybrid/complex glycans in glycoproteins from different organisms (Dwek et al., 1993). Both types of glycosylation occur in $65 \%$ of secreted cellulases, $62.1 \%$ of secreted hemicellulases, while only $O$-glycosylation patterns appear in most of accessory enzymes. The presence of $N$-linked glycans is common for catalytic domain of the enzymes, while $O$-glycosylation usually occurs in linker region. Even though predicted to, non-secreted enzymes are not modified in vivo with glycans, since this procedure has been noticed as a post-translational modification in proteins targeted to the secretory pathway of the cell (Blom et al., 2004).

\section{CONCLUSIONS}

Rapid depolymerization of lignocellulosic material is a distinguishing feature of thermophilic fungi, such as M. thermophila, which was isolated from soil and self-heating masses of composted vegetable matter (Domsch et al., 1993). However, the precise biochemical mechanisms and underlying genetics of this procedure are not completely understood. Systematic examination of the $M$. thermophila genome revealed a unique enzymatic system comprising of an unusual repertoire of auxiliary enzymes, especially those classified to AA9 family, and provided insights into its extraordinary capacity for protein secretion. The current review constitutes, to the best of our knowledge, the first genomic analysis of the lignocellulolytic system of $M$. thermophila. The genomic data, along with the observed enzymatic activity of several isolated and characterized enzymes suggest that this fungus possesses a complete set of enzymes, including 30 cellulases, 66 hemicellulases, and 35 proteins with auxiliary auxiliary enzymes, covering the most of the recognized CAZy families. From its cellulases to its oxido-reductases and multicopper enzymes, $M$. thermophila gene complement 
represents several avenues for further research and its diverse array of enzymatic capabilities will contribute to the study of lignocellulose degradation and the subsequent ethanol biofuel production.

\section{ACKNOWLEDGMENTS}

Anthi Karnaouri thanks the State Scholarships Foundation (Greece) for a Grant. Paul Christakopoulos thanks Bio4Energy, a strategic research environment appointed by the Swedish government, for supporting this work.

\section{REFERENCES}

Baldrian, P. (2006). Fungal laccases-occurrence and properties. FEMS Microbiol. Rev. 30, 215-242. doi: 10.1111/j.1574-4976.2005.00010.x

Beldman, G., Schols, H. A., Pitson, S. M., Searle-van Leeuwen, M. F., and Voragen, A. G. J. (1997). "Arabinans and arabinan degrading enzymes," in Advances in Macromolecular Carbohydrate Research, Vol. 1, ed R. Sturgeon (Stamford, CT: JAI Press Inc), 1-64.

Berka, R. M., Grigoriev, I. V., Otillar, R., Salamov, A., Grimwood, J., Reid, I., et al. (2011). Comparative genomic analysis of the thermophilic biomass-degrading fungi Myceliophthora thermophila and Thielavia terrestris. Nat. Biotechnol. 29, 922-927. doi: 10.1038/nbt.1976

Berka, R. M., Schneider, P., Golightly, E. J., Brown, S. H., Madden, M., Brown, K. M., et al. (1997). Characterization of the gene encoding an extracellular laccase of Myceliophthora thermophila and analysis of the recombinant enzyme expressed in Aspergillus oryzae. Appl. Environ. Microbiol. 63, 3151-3157.

Bhat, K. M., and Maheshwari, R. (1987). Sporotrichum thermophile growth, cellulose degradation and cellulase activity. Appl. Environ. Microbiol. 53, 2175-2182.

Biely, P., Vrsanská, M., Tenkanen, M., and Kluepfel, D. (1997). Endo-b-1,4-xylanase families: differences in catalytic properties. J. Biotechnol. 57, 151-166. doi: 10.1016/S0168-1656(97)00096-5

Blom, N., Sicheritz-Ponten, T., Gupta, R., Gammeltoft, S., and Brunak, S. (2004). Prediction of post-translational glycosylation and phosphorylation of proteins from the amino acid sequence. Proteomics 4, 1633-1649. doi: 10.1002/pmic.200300771

Bukhtojarov, F. E., Ustinov, B. B., Salanovich, T. N., Antonov, A. I., Gusakov, A. V., Okunev, O. N., et al. (2004). Cellulase complex of the fungus Chrysosporium lucknowense: isolation and characterization of endoglucanases and cellobiohydrolases. Biochemistry (Mosc). 69, 542-551. doi: 10.1023/B:BIRY.0000029853.34093.13

Canevascini, G., Borer, P., and Dreyer, J. L. (1991). Cellobiose dehydrogenases of Sporotrichum (Chrysosporium) thermophile. Eur. J. Biochem. 198, 43-52. doi: 10.1111/j.1432-1033.1991.tb15984.x

Charavgi, M. D., Dimarogona, M., Topakas, E., Christakopoulos, P., and Chrysina, E. D. (2013). The structure of a novel glucuronoyl esterase from Myceliophthora thermophila gives new insights into its role as a potential biocatalyst. Acta Crystallogr. D Biol. Crystallogr. 69, 63-73. doi: 10.1107/S0907444912042400

Crepin, V. F., Faulds, C. B., and Connerton, I. F. (2004). Functional recognition of newclasses of feruloyl esterase. Appl. Microbiol. Biotechnol. 63, 647-652. doi: 10.1007/s00253-003-1476-3

Davies, G., and Henrissat, B. (1995). Structures and mechanisms of glycosyl hydrolases. Structure. 3, 853-859. doi: 10.1016/S0969-2126(01)00220-9

De Vries, R. P., Poulsen, C. H., Madrid, S., and Visser, J. (1998). AguA, the gene encoding an extracellular a-glucuronidase from Aspergillus tubingensis, is specifically induced on xylose and not on glucuronic acid. J. Bacteriol. 180, 243-249.

Dimarogona, M., Topakas, E., and Christakopoulos, P. (2013). Recalcitrant polysaccharide degradation by novel oxidative biocatalysts. Appl. Microbiol. Biotechnol. 97, 8455-8465. doi: 10.1007/s00253-013-5197-y

Domsch, K. H., Gams, W., and Anderson, T. H. (1993). Compendium of Soil Fungi. (Reprint of 1980 Ed. Verlag) (New York, NY: Academic Press), 780-783.

Dotsenko, G. S., Semenova, M. V., Sinitsyna, O. A., Hinz, S. W., Wery, J., Zorov, I. N., et al. (2012). Cloning, purification, and characterization of galactomannandegrading enzymes from Myceliophthora thermophila. Biochemistry (Mosc). 77, 1303-1311. doi: 10.1134/S0006297912110090
Duff, S. J. B., and Murray, W. D. (1996). Bioconversion of forest products industry waste cellulosics to fuel ethanol: a review. Biores. Technol. 55, 1-33. doi: 10.1016/0960-8524(95)00122-0

Dwek, R. A., Edge, C. J., Harvey, D. J., Wormald, M. R., and Parekh, R. B. (1993). Analysis of glycoprotein-associated oligosaccharides. Annu. Rev. Biochem. 62, 65-100. doi: 10.1146/annurev.bi.62.070193.000433

Emalfarb, M., Hinz, S., Joosten, V., Koetsier, M., Visser, J., Visser, J., et al. (2012). Novel fungal enzymes. US Patent No. US20120030838 A1.

Gilkes, N. R., Henrissat, B., Kilburn, D. G., Miller, R. C., and Warren, R. A. (1991). Domains in microbial beta 1,4-glycanases: sequence conservation, function ande enzyme families. J. Microbiol. Rev. 55, 303-315.

Gouveia, S., Fernández-Costas, C., Sanromán, M. A., and Moldes, D. (2013). Polymerisation of Kraft lignin from black liquors by laccase from Myceliophthora thermophila: effect of operational conditions and black liquor origin. Bioresour. Technol. 131, 288-294. doi: 10.1016/j.biortech.2012. 12.155

Grishutin, S. G., Gusakov, A. V., Markov, A. V., Ustinov, B. B., Semenova, M. V., and Sinitsyn, A. P. (2004). Specific xyloglucanases as a new class of polysaccharide-degrading enzymes. Biochim. Biophys. Acta 1674, 268-281. doi: 10.1016/j.bbagen.2004.07.001

Grönqvist, S., Buchert, J., Rantanen, K., Viikari, L., and Suurnäkki, A. (2003). Activity of laccase on unbleached and bleached thermomechanical pulp. Enzyme Microb. Technol. 32, 439-445. doi: 10.1016/S0141-0229(02) 00319-8

Gruppen, H., Kormelink, F. J. M., and Voragen, A. G. J. (1993). Water-unextractable cell wall material from wheat flour. A structural model for arabinoxylans. J. Cer. Sci. 18, 111-128. doi: 10.1006/jcrs.1993.1040

Guillén, D., Sánchez, S., and Rodríguez-Sanoja, R. (2009). Carbohydrate-binding domains: multiplicity of biological roles. Appl. Microbiol. Biotechnol. 85, 1241-1249. doi: 10.1007/s00253-009-2331-y

Gusakov, A. V., Antonov, A. I., and Ustinov, B. B. (2008). N-Glycosylation in Chrysosporium lucknowense enzymes. Carbohydr. Res. 343, 48-55. doi: 10.1016/j.carres.2007.10.014

Gusakov, A. V., Punt, P. J., Verdoes, J. C., van der Meij, J., Sinitsyn, A. P., Vlasenko, E., et al. (2011). Fungal Enzymes. Jupiter, FL: Dyadic International (USA), Inc. US Patent No. 7,923,236.

Gusakov, A. V., Salanovich, T. N., Antonov, A. I., Ustinov, B. B., Okunev, O. N., Burlingame, R., et al. (2007). Design of highly efficient cellulose mixtures for enzymatic hydrolysis of cellulose. Biotechnol. Bioeng. 97, 1028-1038. doi: 10.1002/bit.21329

Gusakov, A. V., Sinitsyna, A. P., Salanovicha, T. N., Bukhtojarova, F. E., Markova, A. V., Ustinova, B. B., et al. (2005). Purification, cloning and characterisation of two forms of thermostable and highly active cellobiohydrolase I (Cel7A) produced by the industrial strain of Chrysosporium lucknowense. Enz. Microb. Technol. 36, 57-69. doi: 10.1016/j.enzmictec.2004.03.025

Harris, P. V., Welner, D., McFarland, K. C., Re, E., Poulsen, J. C. N., Brown, K., et al. (2010). Stimulation of lignocellulosic biomass hydrolysis by proteins of glycoside hydrolase family 61: structure and function of a large, enigmatic family. Biochemistry 49, 3305-3316. doi: 10.1021/bi100009p

Henriksson, G., Johansson G., and Pettersson, G. (2000). A critical review of cellobiose dehydrogenases. J. Biotechnol. 78, 93-113. doi: 10.1016/S01681656(00)00206-6

Henrissat, B. (1991). A classification of glycosyl hydrolases based on amino acid sequence similarities. Biochem. J. 280, 309-316.

Hinz, S. W. A., Pouvreau, L., Joosten, R., Bartels, J., Jonathan, M. C., Wery, J., et al. (2009). Hemicellulase production in Chrysosporium lucknowense C1. J. Cer. Sci. 50, 318-323. doi: 10.1016/j.jcs.2009.07.005

Horn, S. J., Vaaje-Kolstad, G., Westereng, B., and Eijsink, V. G. (2012). Novel enzymes for the degradation of cellulose. Biotechnol. Biofuels. 5, 45. doi: 10.1186/1754-6834-5-45

Jun, H., Kieselbach, T., and Jönsson, L. (2011). Enzyme production by filamentous fungi: analysis of the secretome of Trichoderma reesei grown on unconventional carbon source. Microb. Cell Fact. 10, 68. doi: 10.1186/1475-2859-10-68

Karlsson, J., Saloheimo, M., Siika-aho, M., Tenkanen, M., Penttila, M., and Tjerneld, F. (2001). Homologous expression and characterization of Cel61A (EG IV) of Trichoderma reesei. Eur. J. Biochem. 268, 6498-6507. doi: 10.1046/j.0014-2956.2001.02605.x

Karnaouri, A., Topakas, E., Paschos, T., Taouki, I., and Christakopoulos, P. (2013). Cloning, expression and characterization of an ethanol tolerant GH3 
$\beta$-glucosidase from Myceliophthora thermophila. PeerJ 1, e46. doi: 10.7717/ peerj.46

Karnaouri, A. C., Topakas, E., and Christakopoulos, P. (2014). Cloning, expression, and characterization of a thermostable GH7 endoglucanase from Myceliophthora thermophila capable of high-consistency enzymatic liquefaction. Appl. Microbiol. Biotechnol. 98, 231-242. doi: 10.1007/s00253-013-4895-9

Kim, T. J. (2008). "Microbial exo- and endo-arabinosyl hydrolases: structure, function, and application in L-arabinose production," in Carbohydrate-Active Enzymes, ed K. H. Park (Cambridge: CRC Press; Woodhead Publishing Ltd.), 229-257.

Knob, A., Terrasan, C. R. F., and Carmona, E. C. (2010). $\beta$-Xylosidases from filamentous fungi: an overview. World J. Microbiol. Biotechnol. 26, 389-407. doi: 10.1007/s11274-009-0190-4

Kühnel, S., Hinz, S. W., Pouvreau, L., Wery, J., Schols, H. A., and Gruppen, H. (2010). Chrysosporium lucknowense arabinohydrolases effectively degrade sugar beet arabinan. Bioresour. Technol. 101, 8300-8307. doi: 10.1016/j.biortech.2010.05.070

Kühnel, S., Pouvreau, L., Appeldoorn, M. M., Hinz, S. W., Schols, H. A., and Gruppen, H. (2012). The ferulic acid esterases of Chrysosporium lucknowense C1: purification, characterization and their potential application in biorefinery. Enzyme Microb. Technol. 50, 77-85. doi: 10.1016/j.enzmictec.2011. 09.008

Kühnel, S., Westphal, Y., Hinz, S. W., Schols, H. A., and Gruppen, H. (2011). Mode of action of Chrysosporium lucknowense C1 $\alpha$-l-arabinohydrolases. Bioresour. Technol. 102, 1636-1643. doi: 10.1016/j.biortech.2010.09.029

Langston, J. A., Shaghasi, T., Abbate, E., Xu, F., Vlasenko, E., and Sweeney, M. D. (2011). Oxidoreductive cellulose depolymerization by the enzymes cellobiose dehydrogenase and glycoside hydrolase 61. Appl. Environ. Microbiol. 77, 7007-7015. doi: 10.1128/AEM.05815-11

Lindberg, B., Rossel, K. G., and Svensson, S. (1973). Position of the O-acetyl groups in birch xylan. Sven. Papperstidn. 76, 30-32.

Lombard, V., Golaconda Ramulu, H., Drula, E., Coutinho, P. M., and Henrissat, B. (2014). The Carbohydrate-active enzymes database (CAZy) in 2013. Nucleic Acids Res. 42, D490-D495. doi: 10.1093/nar/gkt1178

Lynd, L. R., Weimer, P. J., van Zyl, W. H., and Pretorius, I. S. (2002). Microbial cellulose utilization: fundamentals and biotechnology. Microbiol. Mol. Biol. Rev. 66, 506-577. doi: 10.1128/MMBR.66.3.506-577.2002

Maheshwari, R., Bharadwaj, G., and Bhat, M. K. (2000). Thermophilic fungi: their physiology and enzymes. Microbiol. Mol. Biol. Rev. 64, 461-488. doi: 10.1128/MMBR.64.3.461-488.2000

Margaritis, A., and Merchant, R. F. J. (1986). Thermostable cellulases from thermophilic microorganisms. Crit. Rev. Biotechnol. 4, 327-367. doi: $10.3109 / 07388558609150799$

McCleary, B. V. (1988). ß-D-Mannanase. Meth. Enzymol. 160, 596-610. doi: 10.1016/0076-6879(88)60174-1

Morgenstern, I., Powlowski, J., Ishmael, N., Darmond, C., Marqueteau, S., Moisan, M. C., et al. (2012). A molecular phylogeny of thermophilic fungi. Fungal Biol. 116, 489-502. doi: 10.1016/j.funbio.2012.01.010

Moukouli, M., Topakas, E., and Christakopoulos, P. (2010). “Optimized expression of a GH11 xylanase and a type C feruloyl esterase from Fusarium oxysporum in Pichia pastoris and study of their synergistic action," in Final Workshop, COST Action 928, Control and exploitation of enzymes for added-value products, Poster Presentation (Naples).

Mustafa, R., Muniglia, L., Rovel, B., and Girardin, M. (2005). Phenolic colourants obtained by enzymatic synthesis using a fungal laccase in a hydro-organic biphasic system. Food Res. Int. 38, 995-1000. doi: 10.1016/j.foodres.2005. 02.019

Poutanen, K., Sundberg, M., Korte, H., and Puls, J. (1990). Deacetylation of xylans by acetyl esterases of Trichoderma reesei. J. Appl. Microbiol. Biotechnol. 33, 506-510. doi: 10.1007/BF00172542

Pouvreau, L., Jonathan, M. C., Kabel, M. A., Hinz, S. W., Gruppen, H., and Schols, H. A. (2011a). Characterization and mode of action of two acetyl xylan esterases from Chrysosporium lucknowense $\mathrm{Cl}$ active towards acetylated xylans. Enzyme Microb. Technol. 49, 312-320. doi: 10.1016/j.enzmictec.2011.05.010

Pouvreau, L., Joosten, R., Hinz, S. W., Gruppen, H., and Schols, H. A. (2011b). Chrysosporium lucknowense C1 arabinofuranosidases are selective in releasing arabinose from either single or double substituted xylose residues in arabinoxylans. Enzyme Microb. Technol. 48, 397-403. doi: 10.1016/j.enzmictec.2011.01.004
Punta, M., Coggill, P. C., Eberhardt, R. Y., Mistry, J., Tate, J., Boursnell, C., et al. (2012). The Pfam protein families' database. Nucleic Acids Res. 40, D290-D301. doi: 10.1093/nar/gkr1065

Ribeiro, D. A., Cota, J., Alvarez, T. M., Brüchli, F., Bragato, J., Pereira, B. M., et al. (2012). The Penicillium echinulatum secretome on sugar cane bagasse. PLoS ONE. 7:e50571. doi: 10.1371/journal.pone.0050571

Ruiz-Dueñas, F. J., and Martínez, A. T. (2009). Microbial degradation of lignin: how a bulky recalcitrant polymer is efficiently recycled in nature and how we can take advantage of this. Microb. Biotechnol. 2, 164-177. doi: 10.1111/j.17517915.2008.00078.x

Špániková, S., and Biely, P. (2006). Glucuronoyl esterase-novel carbohydrate esterase produced by Schizophyllum commune. FEBS Lett. 580, 4597-4601. doi: 10.1016/j.febslet.2006.07.033

Shibuya, N., and Iwasaki, T. (1985). Structural features of rice bran hemicellulose. Phytochemistry 30, 488-494.

Sørensen, H. R., Pedersen, S., Jørgensen, C. T., and Meyer, A. S. (2007). Enzymatic hydrolysis of wheat arabinoxylan by a recombinant "minimal" enzyme cocktail containing a-xylosidase and novel endo-1,4-a-xylanase and a-L-arabinofuranosidase activities. Biotechnol. Prog. 23, 100-107. doi: 10.1021/bp0601701

Subramaniam, S. S., Nagalla, S. R., and Renganathan, V. (1999). Cloning and characterization of a thermostable cellobiose dehydrogenase from Sporotrichum thermophile. Arch. Biochem. Biophys. 365, 223-230. doi: 10.1006/abbi.19 99.1152

Sweeney, M. D., and Xu, F. (2012). Biomass converting enzymes as industrial biocatalysts for fuels and chemicals: recent developments. Catalysts 2, 244-263. doi: $10.3390 /$ catal2020244

Szijártó, N., Horan, E., Zhang, J., Puranen, T., Siika-Aho, M., and Viikari, L. (2011). Thermostable endoglucanases in the liquefaction of hydrothermally pretreated wheat straw. Biotechnol. Biofuels 4, 2. doi: 10.1186/1754-6834-4-2

Tambor, J. H., Ren. H., Ushinsky, S., Zheng, Y., Riemens, A., St-Francois, C., et al. (2012). Recombinant expression, activity screening and functional characterization identifies three novel endo-1,4- $\beta$-glucanases that efficiently hydrolyse cellulosic substrates. Appl. Microbiol. Biotechnol. 93, 203-14. doi: 10.1007/s00253-011-3419-8

Tenkanen, M., Siika-aho, M., Hausalo, T., Puls, J., and Viikari, L. (1996). "Synergism between xylanolytic enzymes of Trichoderma reesei in the degradation of acetyl-4-O-methylglucoronoxylan," in Biotechnology in Pulp and Paper Industly Advances in Applied and, Fundamental Research, eds K. Messner and E. Srebotnik (Vienna: WUA Universitatsverlag), 503-508.

Terri, T. T. (1997). Crystalline cellulose degradation: a new insight into the function of cellobiohydrolases. Trends Biotechnol. 15, 160-167. doi: 10.1016/S01677799(97)01032-9

Tolan, J. S., and Foody, B. (1999). Cellulases from submerged fermentation. $A d v$. Biochem. Eng. Biotechnol. 65, 41-67. doi: 10.1007/3-540-49194-5_3

Topakas, E., Christakopoulos, P., and Faulds, C. B. (2005). Comparison of mesophilic and thermophilic feruloyl esterases: characterization of their substrate specificity for methyl phenylalkanoates. J. Biotechnol. 115, 355-366. doi: 10.1016/j.jbiotec.2004.10.001

Topakas, E., Kalogeris, E., Kekos, D., Macris, B. J., and Christakopoulos, P. (2003). Production and partial characterisation of feruloyl esterase by Sporotrichum thermophile in solid-state fermentation. Proc. Biochem. 38, 1539-1543. doi: 10.1016/S0032-9592(03)00044-X

Topakas, E., Moukouli, M., Dimarogona, M., and Christakopoulos, P. (2012). Expression, characterization and structural modelling of a feruloyl esterase from the thermophilic fungus Myceliophthora thermophila. Appl. Microbiol. Biotechnol. 94, 399-411. doi: 10.1007/s00253-011-3612-9

Topakas, E., Moukouli, M., Dimarogona, M., Vafiadi, C., and Christakopoulos, P. (2010). Functional expression of a thermophilic glucuronyl esterase from Sporotrichum thermophile: identification of the nucleophilic serine. Appl. Microbiol. Biotechnol. 87, 1765-1772. doi: 10.1007/s00253-0102655-7

Topakas, E., Stamatis, H., Biely, P., and Christakopoulos, P. (2004). Purification and characterization of a type B feruloyl esterase (StFAE-A) from the thermophilic fungus Sporotrichum thermophile. Appl. Microbiol. Biotechnol. 63, 686-690. doi: 10.1007/s00253-003-1481-6

Topakas, E., Vafiadi, C., and Christakopoulos, P. (2007). Microbial production, characterization and applications of feruloyl esterases. Proc. Biochem. 42, 497-509. doi: 10.1016/j.procbio.2007.01.007 
Ustinov, B. B., Gusakov, A. V., Antonov, A. I., and Sinitsyn, A. P. (2008). Comparison of properties and mode of action of six secreted xylanases from Chrysosporium lucknowense. Enzyme Microb. Technol. 43, 56-65. doi: 10.1016/j.enzmictec.2008.01.017

Vafiadi, C., Topakas, E., Biely, P., and Christakopoulos, P. (2009). Purification, characterization and mass spectrometric sequencing of a thermophilic glucuronoyl esterase from Sporotrichum thermophile. FEMS Microbiol. Lett. 296, 178-184. doi: 10.1111/j.1574-6968.2009.01631.x

van Gool, M. P., van Muiswinkel, G. C., Hinz, S. W., Schols, H. A., Sinitsyn, A. P., and Gruppen, H. (2012). Two GH10 endo-xylanases from Myceliophthora thermophila $\mathrm{Cl}$ with and without cellulose binding module act differently towards soluble and insoluble xylans. Bioresour. Technol. 119, 123-132. doi: 10.1016/j.biortech.2012.05.117

van Gool, M. P., van Muiswinkel, G. C., Hinz, S. W., Schols, H. A., Sinitsyn, A. P., and Gruppen, H. (2013). Two novel GH11 endo-xylanases from Myceliophthora thermophila $\mathrm{Cl}$ act differently toward soluble and insoluble xylans. Enzyme Microb. Technol. 53, 25-32. doi: 10.1016/j.enzmictec.2013. 03.019

Verdoes, J. C., Punt, P. J., Burlingame, R. P., Pynnonen, C. M., Olson, P. T., and Wery, J. (2010). New fungal production system. Patent No. WO2010107 303 A2.

Visser, H., Joosten, V., Punt, P. J., Gusakov, A. V., Olson, P. T., Joosten, R., et al. (2011). Development of a mature fungal technology and production platform for industrial enzymes based on a Myceliophthora thermophila isolate, previously known as Chrysosporium lucknowense C1. Ind. Biotechnol. 7, 214-223. doi: 10.1089/ind.2011.7.214

Weinstein, L., and Albersheim, P. (1979). Structure of plant cell walls: IX. Purification and partial characterization of a wall-degrading endo-arabanase and an arabinosidase from Bacillus subtilis. Plant Physiol. 63, 425-432. doi: 10.1104/pp.63.3.425
Westphal, Y., Kühnel, S., de Waard, P., Hinz, S. W., Schols, H. A., Voragen, A. G., et al. (2010). Branched arabino-oligosaccharides isolated from sugar beet arabinan. Carbohydr. Res. 345, 1180-1189. doi: 10.1016/j.carres.2010.03.042

Zhang, J., Pakarinen, A., and Viikari, L. (2013). Synergy between cellulases and pectinases in the hydrolysis of hemp. Bioresour. Technol. 29, 302-307. doi: 10.1016/j.biortech.2012.11.064

Zhang, Y. H. P., Himmel, M. E., and Mielenz, J. R. (2006). Outlook for cellulose improvement: screening and selection strategies. Biotechnol. Adv. 24, 452-481. doi: 10.1016/j.biotechadv.2006.03.003

Conflict of Interest Statement: The Review Editor Ulrika Rova declares that, despite being affiliated to the same institution as authors Anthi Karnaouri, Io Antonopoulou, and Paul Christakopoulos, the review process was handled objectively and no conflict of interest exists. The authors declare that the research was conducted in the absence of any commercial or financial relationships that could be construed as a potential conflict of interest.

Received: 22 April 2014; accepted: 22 May 2014; published online: 18 June 2014.

Citation: Karnaouri A, Topakas E, Antonopoulou I and Christakopoulos P (2014) Genomic insights into the fungal lignocellulolytic system of Myceliophthora thermophila. Front. Microbiol. 5:281. doi: 10.3389/fmicb.2014.00281

This article was submitted to Microbial Physiology and Metabolism, a section of the journal Frontiers in Microbiology.

Copyright (c) 2014 Karnaouri, Topakas, Antonopoulou and Christakopoulos. This is an open-access article distributed under the terms of the Creative Commons Attribution License (CC BY). The use, distribution or reproduction in other forums is permitted, provided the original author(s) or licensor are credited and that the original publication in this journal is cited, in accordance with accepted academic practice. No use, distribution or reproduction is permitted which does not comply with these terms. 